\title{
Recent marine Ostracoda from the Solomon Islands. Part 4: Cytheroidea; Hemicytheridae, Thaerocytheridae
}

\author{
ROSEMARY TITTERTON ${ }^{1} \&$ ROBIN C. WHATLEY ${ }^{2}$ \\ ${ }^{1}$ Statoil, N-4035, Stavanger, Norway \\ ${ }^{2}$ Institute of Geography \& Earth Sciences, University of Wales, Aberystwyth, UK
}

\begin{abstract}
Eleven species of family Hemicytheridae and seven of the family Thaerocytheridae are described. Together they comprise $14 \%$ of the total Recent ostracod fauna described from the Solomon Islands. In the main the hemicytherids are much more endemic than the thaerocytherids. Three new species have been recorded only from the Solomon Islands, and three species of Caudites, held in open nomenclature due to their rarity, are also probably endemic to the islands. Another three new species have been recorded only from Java and one species of Mimicocythere gen. et sp. nov. also occurs in Australia. The six new species described and illustrated are: Ambostracon (A.) micropapillatum, A. (A.) micromaculata, Caudites shortlandensis, ?C. atypicus, Mutilus dissimilis ssp. nov. and Mimicocythere pseudomelobesoides gen. et sp. nov. Only one of the hemicytherids, Caudites javana Kingma, occurs throughout the Indo-Pacific. It is the Thaerocytheridae, however, that are almost pandemic in tropical regions, with Tenedocythere deltoides and T. transoceanica being distributed particularly widely. A new species of the rare genus Neobuntonia, $N$. subalata sp. nov., only the second modern species to be described, is also illustrated. J. Micropalaeontol. 27(1): 13-33, May 2008.
\end{abstract}

KEYWORDS: Solomon Islands, marine Ostracoda, Hemicytheridae, Thaerocytheridae, Recent

\section{INTRODUCTION}

There has been a resurgence of studies of Ostracoda in the Indo-Pacific area. A listing of the most important publications is given in the introduction of recent papers by the present authors (Titterton \& Whatley, 2005, 2006a, b) and Warne et al. (2006). This contribution is the fourth paper in the current series on the Recent marine Ostracoda of the Solomon Islands. Earlier papers deal with the Xestoleberidae, the Cypridoidea, Platycopina and Cladocopina, and the Bythocytheridae to the Cytheruridae respectively (Titterton \& Whatley, 2005, 2006a, b). Quaternary marine and brackish Ostracoda from the islands are the subject of an additional study (Whatley et al., in press b). Prior to this, apart from Harding's (1962) study of species recovered from the gut of freshwater fishes, and two papers by the present authors on marine taxa (Whatley \& Titterton, 1981; Titterton \& Whatley, 1988), which dealt with two trachyleberidid genera and the large fauna (21 species) of Bairdiinae respectively, the Ostracoda of the Solomon Islands had been sadly neglected.

The Solomon Islands are situated to the NE of Australia and to the SE of New Guinea between Lat. $5^{\circ}-12^{\circ} \mathrm{S}$ and Long. $155^{\circ}-162^{\circ} \mathrm{E}$ and enjoy an oceanic tropical climate. The samples on which this study is based were collected off the islands of Guadalcanal and Shortland (Fig. 1). The location of the samples is given in Figures 2 and 3. All of the samples are of largely biodetrital sand, ranging from very fine to medium in grain size. Much of the medium sand originated from coral and the samples were collected with a simple pipe dredge or by diving. Details of the individual samples can be found in Titterton \& Whatley (1988).

The total ostracod fauna comprises some 160 species belonging to 56 genera. The overwhelmingly dominant group are the Cytheroidea $(63 \%)$; the remainder are cyprids $(15 \%)$, bairdiids $(8 \%)$ and platycopids/cladocopids (13\%). Jointly, there are 18 species of hemicytherids and thaerocytherids; 11 belonging to the former and seven to the latter family. Together they com- prise $14 \%$ of the total ostracod fauna. In the main the Hemicytheridae are much more endemic than the thaerocytherids as six are new species and another three, held in open nomenclature due to their rarity, are probably new. One of the hemicytherids (Caudites javana Kingma), however, is very widespread throughout the Indo Pacific. It is the Thaerocytheridae that are almost pandemic in tropical regions, with Tenedocythere deltoides and $T$. transoceanica being distributed particularly widely.

\section{SYSTEMATIC DESCRIPTIONS}

All the material is housed in the collections of the Natural History Museum, London. The type specimens of all new taxa and the majority of the figured specimens have catalogue numbers between OS 16296 and OS 16389. Other catalogue numbers prefixed RT/SIR refer to the Aberystwyth Collections, also housed in the Natural History Museum. Specimens are of adults unless otherwise stated. All dimensions are given in millimetres, and the size convention for adults is as follows: $<0.40 \mathrm{~mm}$ very small; $0.40-0.50 \mathrm{~mm}$ small; $0.50-0.70 \mathrm{~mm}$ medium; $0.70-1.00 \mathrm{~mm}$ large; $>1.0 \mathrm{~mm}$ very large. Other conventions used throughout are: $\mathrm{LV}$, left valve; $\mathrm{RV}$, right valve; $\mathrm{C}$, carapace; A, adult; rpc, radial pore canal; npc, normal pore canal; LOC, line of concrescence; IM, inner margin; OM, outer margin. All new taxa are described fully.

Order Podocopida Müller, 1894

Suborder Podocopina Sars, 1866

Superfamily Cytheroidea Baird, 1850

Family Hemicytheridae Puri, 1953

Subfamily Hemicytherinae Puri, 1953

Genus Ambostracon Hazel, 1962

Type species. Ambostracon costatum Hazel, 1962. 


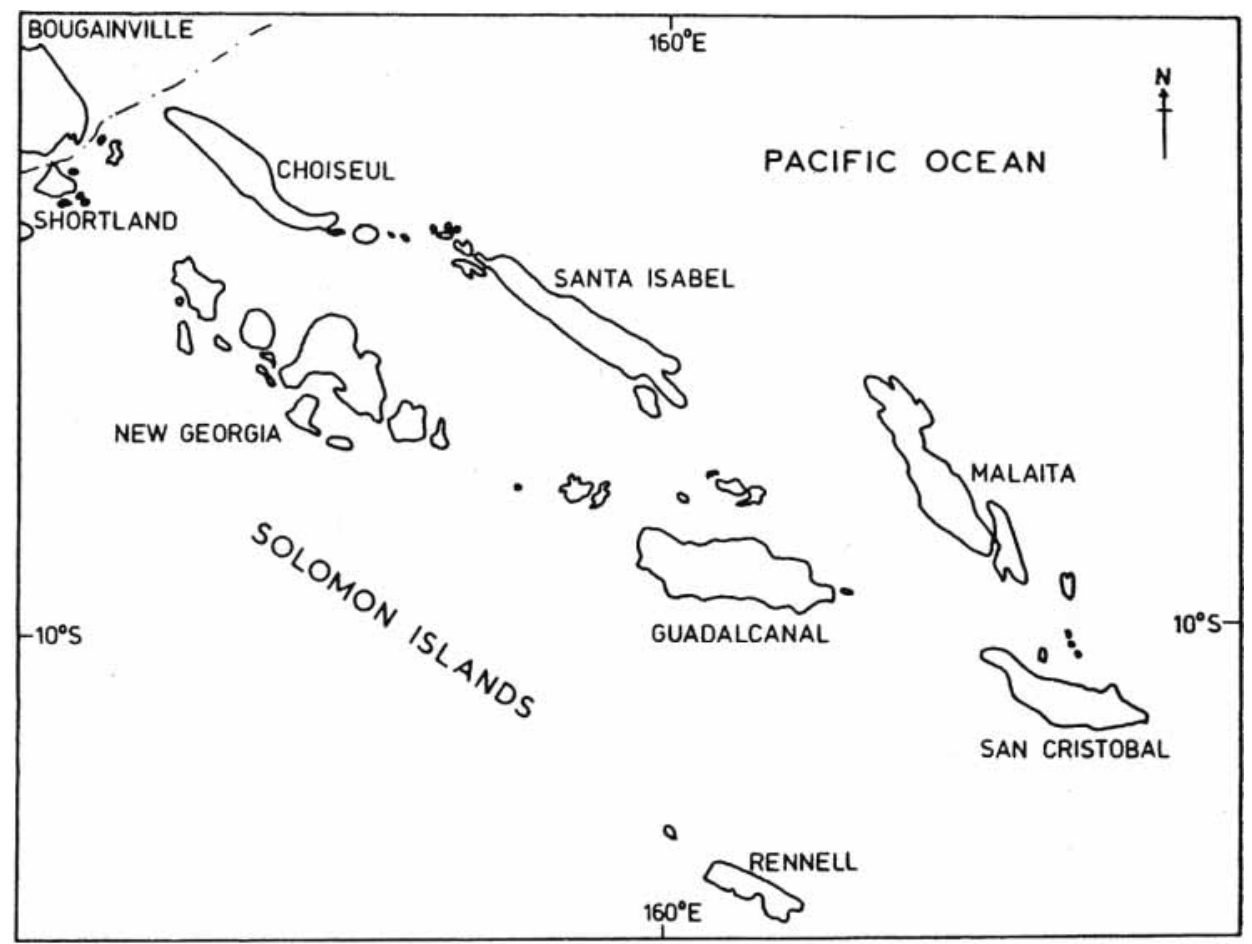

Fig. 1. The Solomon Islands.

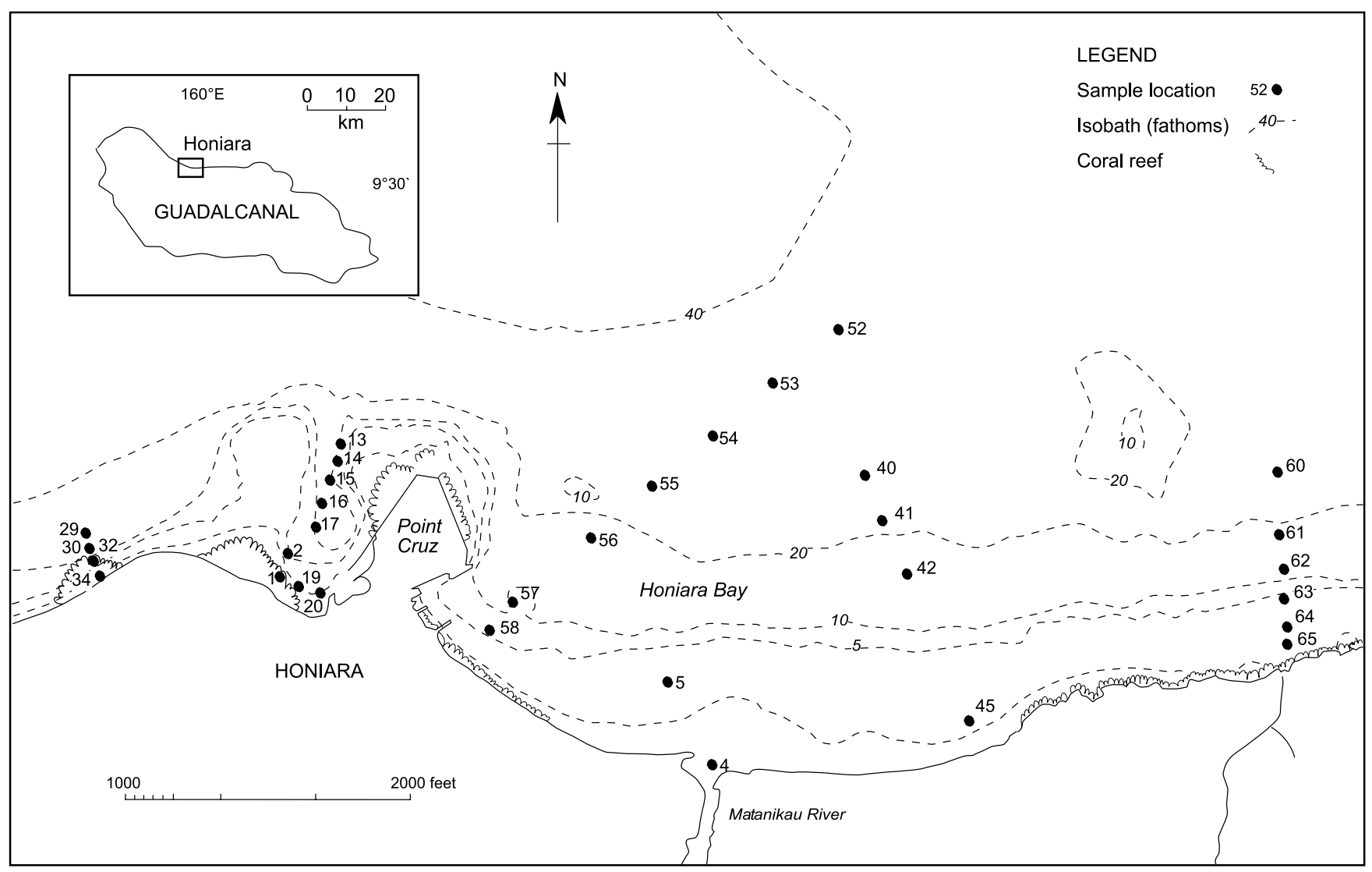

Fig. 2. Location of sample stations, Honiara Bay, N. Guadalcanal, Solomon Islands. 


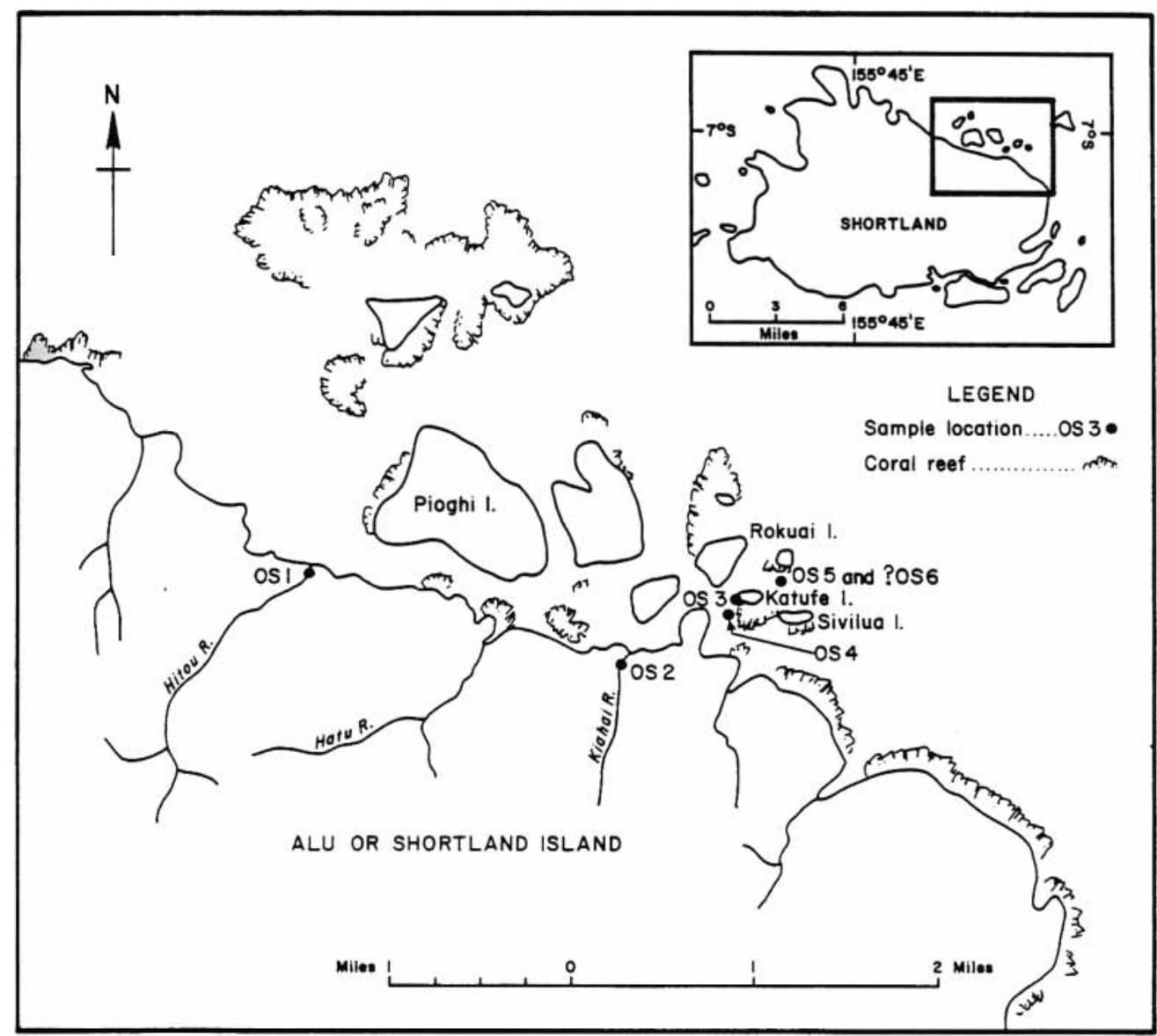

Fig. 3. Location of sample stations, Shortland Island, Solomon Islands.

Remarks. Ambostracon was originally erected by Hazel (1962) as a monotypic genus for a hemicytherid species found in sediments of Pleistocene age from California. Valicenti (1977) considered that Ambostracon and Patagonacythere Hartmann, 1962 (published some months later than Ambostracon) are subgenera of Ambostracon and distinguished them on the degree of the development of the anterior submarginal ocular ridge. This anterior ridge is weakly developed in $A$. (Patagonacythere) but in $A$. (Ambostracon) it forms an ocular ridge varying in strength between different species. Three species of Ambostracon were encountered in the present material and all possess an anterior submarginal ocular ridge and are referred to $A$. (Ambostracon).

Ambostracon is related very closely to several other hemicytherid genera. It is less caudate and more quadrate in outline than Caudites Coryell \& Fields, 1937. Caudites and Orionina Puri, 1954 possess pillar structures within the anterior vestibulum, formed by the fusion of two lamellae. These structures are absent in Ambostracon. Ambostracon is more elongate and subrectangular in outline than the quadrate Mutilus Neviani, 1928, and the former lacks the vertically incised posterior tooth of the RV hinge characteristic of Mutilus and Aurila Pokorny, 1955.
Subgenus Ambostracon (Ambostracon) Hazel, 1962

Ambostracon (Ambostracon) variornatum (Hartmann), 1978

(Fig. 4, nos 4, 5; P1. 1, figs 1-9)

1978 Mutilus variornatus Hartmann: 98, T.-figs 213-222; pl. 8, figs 1-9.

1978 Mutilus variornatus Hartmann (sic); Hartmann \& Kuhl: 221, pl. 29, figs 55-64.

Material. Approximately 1000 valves and carapaces, A-3 to adult. Samples 1, 2, 13-15, 19, 29, 32, 55, 59, 61, 0S3-0S6 Guadalcanal and Shortland islands.

Description. Surface of valve costate/reticulate with series of irregular ribs which may vary in development between individuals, with irregular intercostal reticulation and prominent pore conuli. Hinge holamphidont with smooth median element and lacking auriline toothlet in posterior terminal socket of LV. Central muscle scars comprise a single ventral and dorsal scar, two subdivided median scars and two subovate frontal scars. 

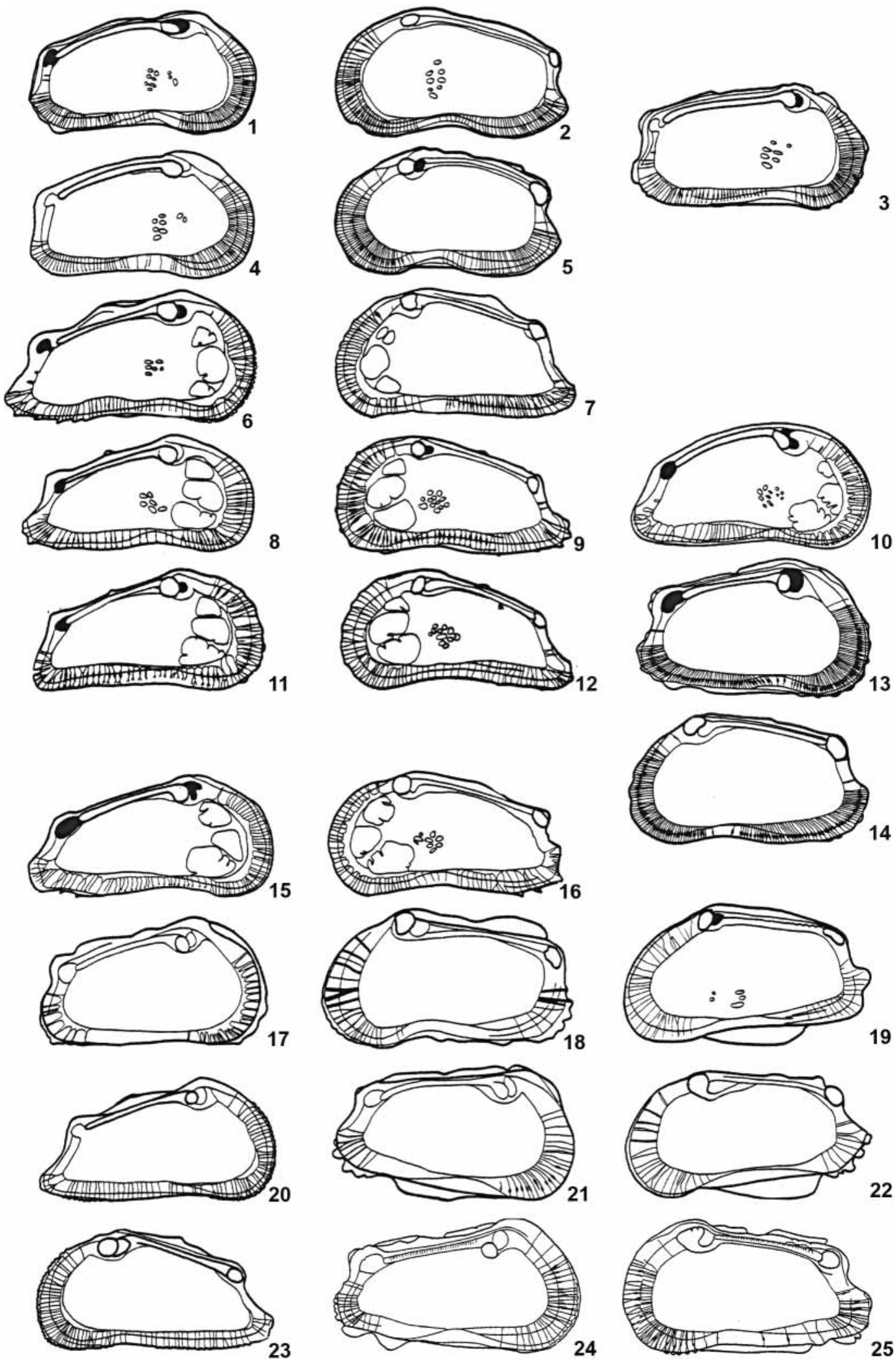


\section{Dimensions.}

Female C, OS 16319

Female C, OS 16320

Female LV, OS 16318

Male C, OS 16321

Male LV, OS 16299

Female RV, OS 16300

A-1 LV, OS 16322

Length
0.54
0.57
0.58
0.57
0.56
0.58
0.46

Height
0.33
0.33
0.36
0.35
0.32
0.36
0.28

Width

0.28

0.26

Occurrence. Hartmann (1978) recorded A. (A.) variornatum from Recent eulittoral sediments from the western coast of Australia.

Remarks. This species does not belong to Mutilus Neviani, 1928 as the posterior tooth of the right valve hinge is not incised; rather, it is lobate, a common feature of many species of Ambostracon of both subgenera. Hartmann \& Kuhl (1978) showed this species to be very variable in ornament, ranging from almost smooth to strongly reticulate and ribbed. Ambostracon (A.) micropapillatum sp. nov. of the present study differs in the position of the lateral ribs and it possesses distinctly pointed posterodorsal and posteroventral swellings. The females are more inflated than the male but both sexes are similar in size, the male being slightly less high.

Ambostracon (Ambostracon) micromaculatum sp. nov. (Fig. 4, no. 3; Pl. 1, figs 10-13)

Derivation of name. Latin; with reference to the small, white, spot-like papillae of the secondary ornament.

Diagnosis. A species of Ambostracon (Ambostracon), characterized by a strongly reticulate surface ornament, weakly concentric around the subcentral tubercle on which the reticulae are smaller with no lateral ribs and a secondary ornament of very fine papillae in the fossae. Distinct, sub-peripheral, ocular rib that extends into an antero-marginal rib, paralleling the margin and terminating at the anteroventral angle. Hinge holamphidont with smooth median element.

Holotype. Female LV, OS 16298.

Paratypes. Female LV, OS 16323; A-1 RV, OS 16324.

Locality and horizon. Sample 14, $1400 \mathrm{ft}$ offshore, west of Point Cruz, Honiara Bay, Guadalcanal. 10 fathoms. Unconsolidated, medium, coral, sand. Recent.

Material. Four adult valves and 35 juveniles to A-2 instar. Samples: 2, 13-17, 20, 29, 32, 55, 57-59, Guadalcanal.
Description. Medium. Thick-shelled. Translucent. Sexual dimorphism conspicuous; male less inflated than female. Subrectangular in shape in lateral view: subovate in dorsal view. Anterior margin broadly rounded: extremity at mid-height. Posterior margin narrower, bluntly caudate: extremity below mid-height. Dorsal margin very gently arched: cardinal angles prominent, rounded. Ventral margin almost straight; shallow oral concavity. Greatest length through posterior extremity, below midheight; greatest height at anterior cardinal angle; greatest width through subcentral tubercle. Valves with two small, tubercular posterolateral swellings, one dorsal and one ventral: subcentral tubercle inconspicuous. Eye tubercle small, conspicuous, glassy. Surface of valves strongly reticulate: weak concentric orientation around subcentral tubercle on which reticulae are smaller. Distinct, subperipheral, anterior ocular rib terminating at anteroventral angle. Secondary ornament of very fine, circular papillae. Npc few, large, evenly spaced mostly on muri of reticulum, posteriorly some with pore conuli. Inner lamella moderately wide: LOC and IM subparallel to OM. Narrow, crescentic anterior vestibulum. Approximately 54 anterior and 41 posterior rpc, simple, straight, regularly spaced, slightly inflated medianly. Selvage very strong and broad, narrow irregular flange groove. Hinge holamphidont: LV anterior terminal element a deep socket bounded ventrally by an anti-slip bar; anteromedian element a strong, small ovate tooth; posteromedian element a long smooth bar; posterior terminal element a deep socket open ventrally. Central muscle scars in subcentral tubercle depression, small, ovate: median two adductor scars subdivided; dorsal and ventral scars single; two ovate frontal scars.

\section{Dimensions.}

Holotype Female LV, OS 16298

Paratype Female LV, OS 16323

Paratype A-1 RV, OS 16324

$\begin{array}{ll}\text { Length } & \text { Height } \\ 0.58 & 0.36 \\ 0.58 & 0.36 \\ 0.46 & 0.28\end{array}$

Occurrence. This species was also encountered by Watson (1988 MS) from the Java Sea.

Remarks. The present species differs from $A$. (A.) variornatum and $A$. (A.) micropapillatum sp. nov., in that the surface of the valve is reticulate with no lateral ribs. Procythereis (Serratocythere) densuireticulata Hartmann, 1981, from the Recent off Eastern Australia, externally resembles the present species in possessing a similar, reticulate ornament.

\section{Ambostracon (Ambostracon) micropapillatum sp. nov.}

(Fig. 4, nos 1, 2; Pl. 1, figs 14-23)

Derivation of name. Latin; with reference to the micropapillate nature of the fossae of the reticulum, particularly in the anterior region.

Fig. 4. Internal lateral views. 1, 2, Ambostracon (Ambostracon) micropapillatum sp. nov.: 1, LVM, OS $16296 \times 63.2 ; \mathbf{2}, \mathrm{RVF}$, OS $16297 \times 59.0 . \mathbf{3}$, Ambostracon (Ambostracon) micromaculatum sp. nov., Holotype LVF, OS $16298 \times 63.7 .4,5$, Ambostracon (Ambostracon) variornatum (Hartmann) 1978: 4, LVM, OS $16299 \times 62.5 ;$ 5, RVF, OS $16300 \times 62.1$. 6, 7, Caudites shortlandensis sp. nov.: 6, LVM, OS 16301 ×65.1; 7, RVF, OS 16302 $\times$ 74.5. 8, 9, Caudites javana Kingma, 1948: 8, LV, RT/SIR/307 × 72.0; 9, RV, OS $16303 \times 67.9$. 10, Caudites sp. C, RV, OS 16304 ×69.1. 11, 12, Caudites sp. A: 11, LV, OS $16305 \times 78.3 ; \mathbf{1 2}$, RV, OS $16344 \times 82.2 .13,14$, Mutilus dissimilis sp. nov.: 13, LV, OS $16352 \times 57.0 ; 14, \mathrm{RV}$, OS 16306 $\times$ 62.3. 15, 16, Caudites sp. B: 15, LV, OS $16307 \times 70.4 ; \mathbf{1 6}$, RV, OS $16308 \times 71.2 .17,18$, Tenedocythere deltoides (Brady, 1890): 17, LVM, OS 16309

$\times 65.7 ; \mathbf{1 8}$, RVF, OS $16310 \times 66.1$. 19, Neobuntonia subalata sp. nov., Paratype RVF, OS $16311 \times 69.6 .20,23, ?$ Caudites atypicus sp. nov.: 20, LVM, OS $16312 \times 74.0 ; \mathbf{2 3}, \mathrm{RVF}$, OS $16313 \times 74.0 . \mathbf{2 1}, \mathbf{2 2}$, Tenedocythere transoceanica $($ Teeter, 1975): 21, LV, OS $16314 \times 60.5 ; \mathbf{2 2}$, RV, OS $16315 \times 60.3$. 24, 25, Tenedocythere elongata (Hu, 1979): 24, LV, OS $16316 \times 47.0 ; \mathbf{2 5}$, RV, OS $16317 \times 47.6$. 


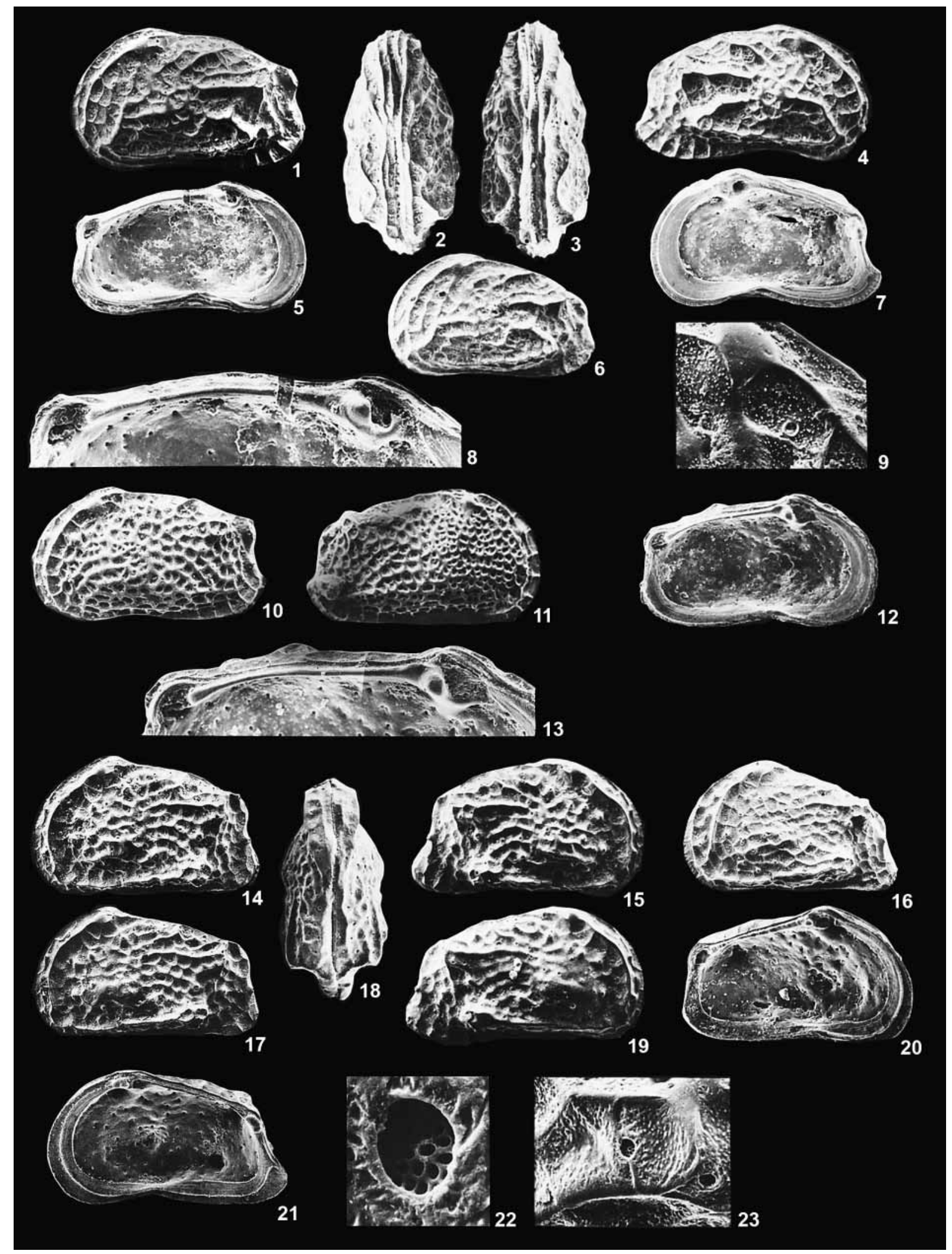


Diagnosis. A species of Ambostracon (Ambostracon) with a distinct ocular rib and reticulate primary ornament, of which there is a strong, oblique orientation of the muri in the posterior region. Secondary ornament of fine papillae that are often elongated, except on crests of prominent muri. Valves swollen posterolaterally with conspicuous posteroventral and posterodorsal swellings. Hinge holamphidont with conspicuously crenulate median element.

\section{Holotype. Female LV, OS 16325.}

Paratypes. Female C, OS 16329; Male LV, OS 16328; Male RV, OS 16330.

Material. 111 valves and carapaces, A-3 to adult. Samples: 1, 2, 13-15, 19, 29, 32, 55, OS3, OS5, OS6 Guadalcanal and Shortland islands.

Locality and horizon. Sample 14, $1400 \mathrm{ft}$ offshore, west of Point Cruz, Honiara Bay, Guadalcanal. 10 fathoms. Unconsolidated, medium-grained coral sand. Recent.

Description. Medium. Thick-shelled. Opaque. Sexual dimorphism conspicuous; male less high and less tumid than female. Subquadrate to subrectangular in lateral view: hastate in dorsal view. Anterior margin broadly rounded: extremity at midheight. Posterior margin narrower, bluntly caudate; more upswept in RV: extremity below mid-height. Dorsal margin gently arched, sloping to posterior: anterior cardinal angle rounded; posterior angle more prominent. Ventral margin with distinct oral concavity. Greatest length below mid-height; greatest height at anterior cardinal angle; greatest width at posterior third. RV slightly longer than LV but LV overlaps RV at cardinal angles. Valves with posterodorsal and a posteroventral swellings, subcentral tubercle not pronounced. Surface reticulate with distinct, subperipheral anterior ocular rib extends from the glassy eye tubercle and continues ventrally, subparallel to anterior margin with a slight interruption at the anteroventral angle, to the ventrolateral swelling. A less distinct rib extends anterolaterally for half the length from the posterodorsal swelling. Strong oblique orientation of reticular muri across the lateral surface in posterior region, more or less well developed in different individuals. Secondary ornamentation of very fine papillae, many of which are elongated, except on crests of prominent muri which are smooth. Npc few, evenly distributed, sieve-type, commonly on pore conulae. Inner lamella moderately wide, LOC and IM subparallel to OM: narrow crescentic anterior vestibule. Approximately 47-52 anterior and 39-41 posterior rpc; straight, simple, slightly inflated medianly. Sub- peripheral selvage, very strongly and broadly developed. Hinge holamphidont: RV anterior terminal element a bilobate tooth; anteromedian element a deep socket bounded ventrally by an anti-slip bar; anteromedian element a long, straight, denticulate groove with four small, widely spaced teeth distally; posterior terminal element a crescentic dentate ridge with 4-5 lobes; LV complementary. Central muscle scars small, ovate; median two adductor scars divided into two; dorsal and ventral scars single; two ovate frontal scars.

\section{Dimensions.}

Holotype Female LV, OS 16325

Paratype Female C, OS 16329

Paratype Male LV, OS 16328

Paratype Male RV, OS 16330

Female RV, OS 16326

Female LV, OS 16331

Male RV, OS 16332

Male LV, OS 16296

Female RV, OS 16297

A-1 LV, OS 16327

$\begin{array}{ll}\text { Length } & \text { Heigh } \\ 0.58 & 0.36 \\ 0.59 & 0.33 \\ 0.60 & 0.32 \\ 0.60 & 0.35 \\ 0.61 & 0.36 \\ 0.59 & 0.36 \\ 0.61 & 0.35 \\ 0.57 & 0.32 \\ 0.61 & 0.36 \\ 0.48 & 0.28\end{array}$

Width

0.28

Remarks. The posteroventral and posterodorsal swelling of the valves distinguish the present species from Mutilus pumila (Brady), 1866 of Hartmann (1981) from the Recent off Eastern Australia and from $A$. (A.) variornatum (Hartmann), 1978 which the present species most closely resembles. Precocious sexual dimorphism is not apparent.

\section{Genus Caudites Coryell \& Fields, 1937}

Type species. Caudites medialis Coryell \& Fields, 1937.

Remarks. Coryell \& Fields (1937) in their type description of the genus did not describe the distinctive pillar structures which are characteristic of Caudites, Orionina Puri, 1954, Anterocythere McKenzie \& Swain, 1967 and Palaciosa Hartmann, 1959. Caudites may be distinguished from the other five genera by its shape; being more elongate and caudate posteriorly and its costate ornament. Also, species of Orionina characteristically possess a reticulate surface ornament.

Caudites javana Kingma, 1948

(Fig. 4, nos 8, 9; P1. 2, figs 1-7)

1948 Caudites medialis Coryell \& Fields var. javana Kingma: 85, p1. 10, figs $5 \mathrm{a}, \mathrm{b}$.

1968 Caudites javana Kingma; Guha: 64, pl. 5, figs, 13, 19.

1978 Caudites cf. javana Kingma; Hartmann: 101, t-figs 240 246; pl. 9, figs 8, 9.

Explanation of Plate 1.

figs 1-9. Ambostracon (Ambostracon) variornatum (Hartmann) 1978: 1, LVF, OS 16318 external lateral view $\times 65.5 ; 2$, CF, OS 16319 dorsal view $\times 63.2 ; \mathbf{3}, \mathrm{CM}$, OS 16320 dorsal view $\times 66.7 ; \mathbf{4}, \mathbf{9}, \mathrm{CM}$, OS $16321-\mathbf{4}$, external lateral view of RV $\times 64.9, \mathbf{9}$, detail of lateral ornament over eye tubercle $\times 301.8 ; \mathbf{5}, \mathbf{8}, \mathrm{LVM}$, OS $16299-\mathbf{5}$, internal view $\times 67.9, \mathbf{8}$, detail of hinge $\times 146.5 ; \mathbf{6}, \mathrm{A}-1 \mathrm{LV}$, OS 16322 external lateral view $\times 73.9 ; \mathbf{7}$, RVF, OS 16300 internal view $\times 65.5$. figs 10-13. Ambostracon (Ambostracon) micromaculatum sp. nov.: 10, Paratype LVF, OS 16323 external lateral view $\times 65.5 ; \mathbf{1 1}$, Paratype A-1RV, OS 16324 external lateral view $\times 82.6 ; \mathbf{1 2}, \mathbf{1 3}$, Holotype LVF, OS $16298-\mathbf{1 2}$, internal view $\times 67.2, \mathbf{1 3}$, detail of hinge $\times$ 123.2. figs 14-23. Ambostracon (Ambostracon) micropapillatum sp. nov.: 14, 22, 23, Holotype LVF, OS $16325-14$, external lateral view $\times 63.8$, 22, detail of normal pore $\times 1871.7, \mathbf{2 3}$, detail of lateral ornament $\times 390.6$; 15, RVF, OS 16326 external lateral view $\times 62.3 ; \mathbf{1 6}$, A-1 LV, OS 16327 external lateral view $\times 72.9 ; 17$, Paratype LVM, OS 16328 external lateral view $\times 60.0 ; 18$, Paratype ACF, OS 16329 dorsal view $\times 61.0 ; 19$, Paratype RVM, OS 16330 external lateral view $\times 65.0 ; \mathbf{2 0}$, LVF, OS 16331 internal view $\times 63.6 ; 21$, RVM, OS 16332 internal view $\times 63.9$. 


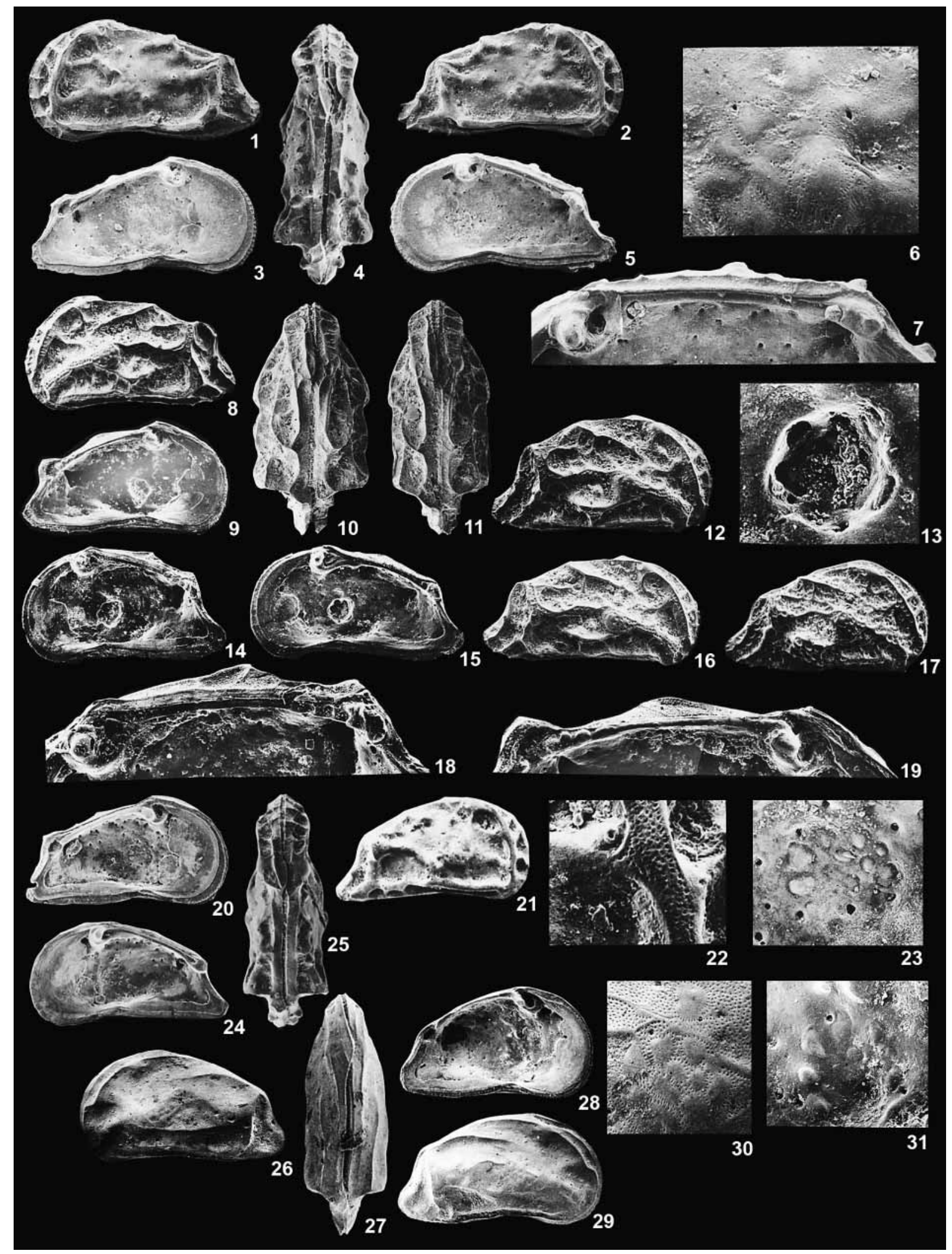


1978 Caudites javana Kingma; Jain: 122, figs 4F 1-3.

1989b Caudites javana Kingma; Zhao \& Whatley: 244, pl. 4, figs $13,14$.

2001 Caudites javana Kingma; Mohan et al.: 8, pl. 3, fig. 11.

2001 Caudites javana Kingma; Hussain \& Mohan: 54.

non 1953 Caudites javana Kingma; Keij: 159, pl. 1, figs 8a, b.

non 1954 Caudites javana Kingma; Keij: 385, pl. 2, figs 12, 13.

non 1986 Caudites javana Kingma; Cabioch et al.: 27, pl. 9,

figs 11, 12. [?=Caudites munita Bonaduce et al., 1980].

non 1989 Caudites cf. javana Kingma; Howe \& McKenzie: 39, fig. 162.

non 1998 Caudites javana Kingma; Hussain: 11, pl. 2, fig. 15.

Diagnosis. A species of Caudites, characterized by a prominent posterodorsal loop and an ornament of strong ribs with smooth intercostal areas. Subperipheral, ocular rib subparallels the anterior margin and then extends posteriorly as the ventrolateral rib. Anteriorly the rib is buttressed by distally notched or tooth-like, small ribs anteriorly. A prominent vertically aligned rib extends from posterodorsal swelling to the ventrolateral rib.

Material. Six adult valves and carapaces. Samples: 2, 17, 30, 56, 57, Guadalcanal.

\section{Dimensions.}

C, OS 16334

RV, OS 16303

C, OS 16333

RV, OS 16335

C, RT/SIR/309

LV, RT/SIR/307

Length
0.51
0.53
0.52
0.53
0.52
0.50

Height

0.27

0.26

0.27

0.28

0.28

0.27

Occurrence. As the synonymy shows, this is a very widespread species, in the Malaysian, Indonesian, Australian, Solomon Islands areas. Jain (1978: 122) reported it from the Gulf of Manaar, Ceylon (Sri Lanka), the Recent of the Persian Gulf and the Neogene of the Andaman Islands.

Remarks. The present species is very similar to Caudites sp. A and Caudites sp. B of the present study. All three species are similarly ornamented by a series of strong ribs with smooth intercostal areas and a prominent posterodorsal loop but may be distinguished by detailed study of the posterolateral ribs. In Caudites sp. A the posterolateral rib extends ventrally from the posterodorsal swelling and curves towards the posterior extremity; this rib in the present species is vertical. The ventrolateral rib also differs, in Caudites sp. A it is expanded medianly but in the present species it becomes expanded posteriorly. Caudites sp. B differs in that the rib extending ventrally from the posterodorsal loop bifurcates medianly; one rib branches towards the anterior and the other towards the posterior extremity. Caudites sp. B is also distinct in that the anterior ocular ridge is interrupted anteroventrally and there is no median dorsal tubercle. One of us (RCW) has seen original material of $C$. javana from the Kingma collection and this was illustrated by him with Zhao (Zhao \& Whatley, 1989b). It is agreed that the two species attributed to $C$. javana by Keij $(1953,1954)$ from the Java Sea and the Philippines respectively, are not conspecific with that species and represent two distinct species. Caudites cf. javana Howe \& McKenzie, 1989 from Northern Australia, is quite dissimilar and certainly not comparable with C. javana.

Caudites shortlandensis sp. nov.

(Fig. 4, nos 6, 7; Pl. 2, figs 8-19)

Derivation of name. Latin; with reference to the type locality, Shortland Island.

Diagnosis. A species of Caudites strongly ornamented by a series of numerous ribs and fine irregular intercostal reticulation and puncta on some ribs and subcentral tubercle. A distinct rib curves over dorsal margin to below eye tubercle. Anterior and ventral margins with frill-like marginal denticulation except in oral region. Posterodorsal margin strongly concave, caudal process subventral.

Holotype. Female RV, OS 16339.

Paratypes. Male RV, OS 16342; Male C, OS 16338; Female C, OS 16337.

Material. 250 adult valves and carapaces and 106 juveniles to A-3 instar. Samples: 1, 14, 29, 58, 62, OS5, OS6 Guadalcanal and Shortland islands.

Locality and horizon. Sample OS6. Exact location unknown, but thought to be from the intertidal zone near a coral reef, off the northeast coast of Shortland Island, in the vicinity of Rokuai Island. Coarse-grained coral sand. Recent.

Explanation of Plate 2.

figs 1-7. Caudites javana Kingma, 1948: 1, AC, OS 16333 external lateral view of RV $\times 73.1 ; \mathbf{2}, \mathbf{6}$, RV, OS $16303-2$, external lateral view $\times 70.8$, 6, detail of lateral ornament over central muscle scar area $\times 351.9 ; 3$, LV, RT/SIR/307 internal view $\times 74.0 ; 4$, AC, OS 16334 dorsal view $\times 82.4$; $\mathbf{5 , 7}, \mathrm{RV}$, OS $16335-\mathbf{5}$, internal view $\times 69.8$, 7, detail of hinge $\times 175.9$. figs 8-19. Caudites shortlandensis sp. nov.: 8, 9, 19, LVM, OS 16336-8, external lateral view $\times 64.2,9$, internal view $\times 62.3$, 19, detail of hinge $\times 170.9 ; 10$, Paratype CF, OS 16337 dorsal view $\times 67.3 ; 11$, Paratype CM, OS 16338 dorsal view $\times 74.5 ; \mathbf{1 2}$, Holotype RVF, OS 16339 external lateral view $\times 66.7$; 13, 15, RVM, OS $16340-13$. detail of normal pore $\times 366.6$, $\mathbf{1 5}$, internal view $\times 68.6 ; \mathbf{1 4}, \mathbf{1 8}, \mathrm{RVF}$, OS $16302-\mathbf{1 4}$, internal view $\times 64.2, \mathbf{1 8}$, detail of hinge $\times 159.7 ; \mathbf{1 6}$, Paratype RVM, OS 16342 external lateral view $\times 68.6 ; \mathbf{1 7}$, A-1 RV, OS 16341 external lateral view $\times 73.3$. figs 20-25. Caudites sp. A: 20, 23, LV, OS 16305-20, internal view $\times 71.7, \mathbf{2 3}$, detail of central muscle scars $\times 330.0 ; \mathbf{2 1}, \mathrm{RV}, \mathrm{RT} / \mathrm{SIR} / 311$ external lateral view $\times 68.5 ; \mathbf{2 2}, \mathbf{2 4}, \mathrm{RV}, \mathrm{OS} 16344-\mathbf{2 2}$, detail of lateral ornament $\times 393.3, \mathbf{2 4}$, internal view $\times 72.2 ; \mathbf{2 5}$, AC, OS 16345 dorsal view $\times 84.4$. figs 26-31. Caudites sp. C: 26, 28, 31. LV, OS $16304-26$, external lateral view $\times 60.9$, 28, internal view $\times 58.2, \mathbf{3 1}$, detail of central muscle scars $\times 254.5 ; \mathbf{2 7}, \mathbf{2 9}, \mathbf{3 0}, \mathrm{AC}$, OS $16346-\mathbf{2 7}$, dorsal view $\times 72.2,29$, external lateral view $\times 61.1$, 30, detail of lateral ornament over central muscle scar area $\times 251.1$. 


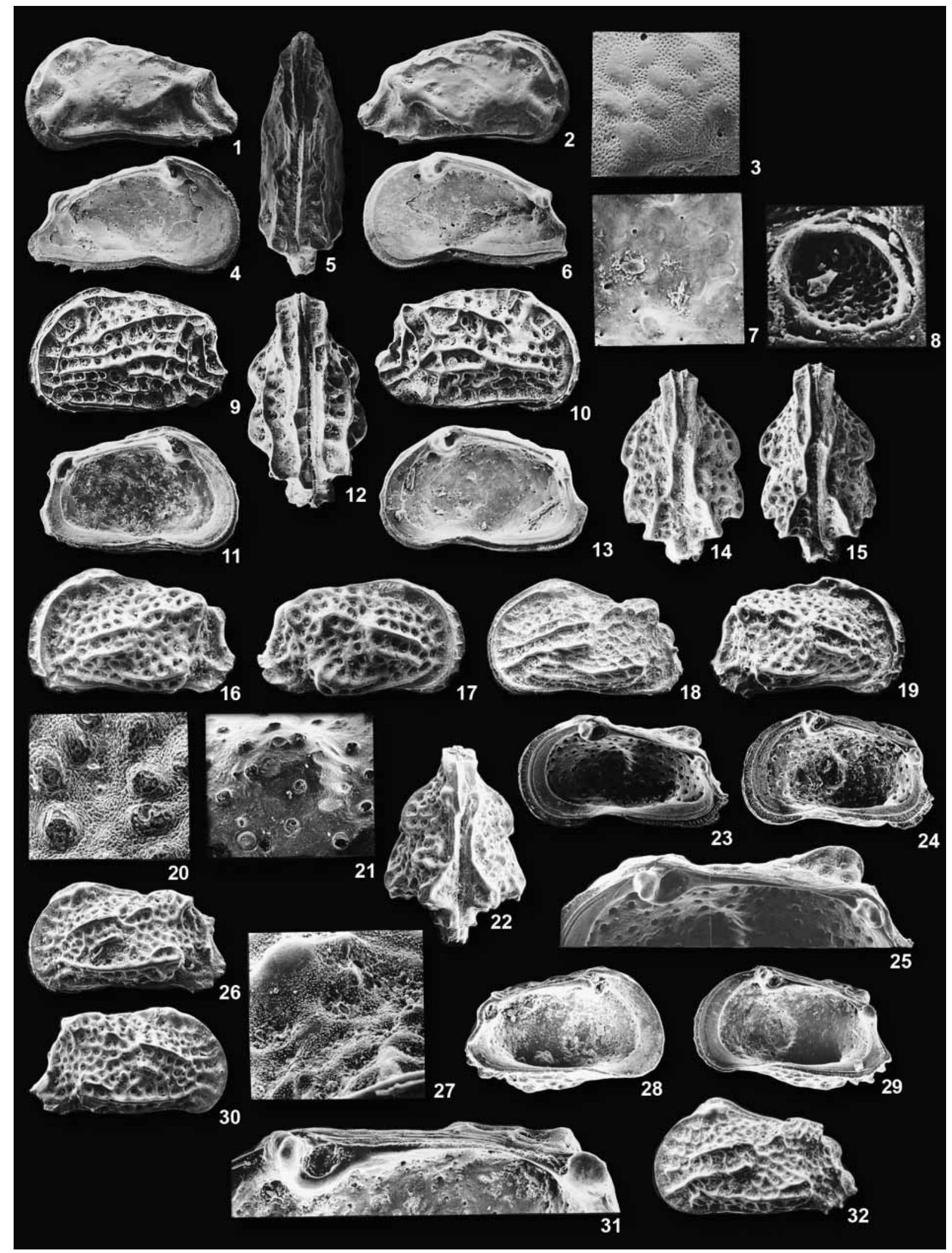


Description. Small to medium. Thick-shelled. Opaque. Male smaller and less tumid than female. Subtriangular in lateral view, sub-elliptical in dorsal view. Anterior margin obliquely rounded with many, small, frill-like marginal denticles continuing into ventral margin; extremity at mid-height. Posterior margin strongly caudate; posterodorsal slope deeply concave: extremity subventral. Dorsal margin, straight, inclined posteriorly, overhung by lateral swelling so as to appear arched. Cardinal angles prominent, except anterior angle of RV. Ventral margin gently biconvex bearing frill-like marginal denticles except in oral region; posteroventrally four small but distinct, backswept marginal spines. Greatest length subventral; greatest height through anterior cardinal angle; greatest width through subcentral tubercle. LV overlaps RV at anterior cardinal angle. Valves inflated, posterodorsally below the posterior cardinal angle and posteroventrally. Conspicuous but small, glassy eye tubercle. Strongly ornamented by a series of numerous ribs and fine, irregular intercostal reticulation. An anterior subperipheral, ocular/anterior ridge bifurcates near the anteroventral angle, one short branch to anterior margin, second branch becoming the ventrolateral rib. A broad, oblique lateral rib extends from anteroventral marginal rib across subcentral tubercle and then posteriorly to meet a broad rib extending vertically from posterodorsal angle; at this point the latter rib becomes less broad and curves posteriorly to meet ventral margin near posterior extremity. A ventral rib curves from subcentral tubercle over posteroventral swelling, to join the strong posterior rib. A peripheral posterodorsal rib ends at posterior extremity. A strong rib curves over dorsal margin midway along its length and continues obliquely anteriorly to area below eye tubercle. Secondary ornamentation of very fine puncta in fossae and reticulae on broad ribs and subcentral tubercle. Npc few, large, widely distributed. Inner lamella wide: LOC and IM subparallel to $\mathrm{OM}$, coincident except anteriorly where narrow crescentic vestibule occurs. Approximately 37 anterior and 29 posterior rpc, canals branching at posterior caudal process and particularly anteroventrally, others simple, all almost straight, slightly swollen medianly. Selvage robust, more peripheral in LV; wide, etched flange groove. Hinge holamphidont: RV anterior terminal element complex comprising a ventral single tooth on broader platform which becomes dentate dorsally with a ridge of six teeth; antero-median element a deep socket bounded ventrally by an anti-slip bar; posteromedian element a long groove becoming locellate posteriorly; posterior terminal element a long, irregular trilobate tooth; very narrow accommodation groove dorsally; LV complementary. Central muscle scars a vertical row of three, probably four, elongate adductor scars with two ovate frontal scars.

$\begin{array}{llll}\text { Dimensions. } & & & \\ & \text { Length } & \text { Height } & \text { Width } \\ \text { Holotype Female RV, OS 16339 } & 0.54 & 0.29 & \\ \text { Paratype Male RV, OS 16342 } & 0.51 & 0.28 & \\ \text { Paratype Male C, OS 16338 } & 0.51 & 0.26 & 0.21 \\ \text { Paratype Female C, OS 16337 } & 0.55 & 0.29 & 0.28 \\ \text { Male LV, OS 16336 } & 0.53 & 0.28 & \\ \text { Male RV, OS 16340 } & 0.51 & 0.26 & \\ \text { Female RV, OS 16302 } & 0.53 & 0.28 & \\ \text { Male LV, OS 16301 } & 0.51 & 0.27 & \\ \text { A-1 RV, OS 16343 } & 0.45 & 0.26 & \end{array}$

Occurrence. Watson (1988 MS) encountered this species in the Java Sea.

Remarks. Caudites shortlandensis is ornamented more strongly than other species of the genus encountered in the present study. Externally it is most similar to ?Caudites atypicus sp. nov., but differs in its strong, broad lateral rib crossing the subcentral tubercle from the anteroventral angle to the vertical posterior rib. ?Caudites atypicus sp. nov. possesses three subparallel postero-lateral ribs.

Caudites sp. A

(Fig. 4, nos 11, 12; P1. 2, figs 20-25)

Material. Three valves and one carapace, all adult. Samples: 2, 14, 17, 29, Guadalcanal.

Description. Elongate, subtriangular in lateral view: subelliptical in dorsal view. Anterior margin broadly rounded with many small, frill-like marginal denticles. Posterior margin strongly caudate. Ventral margin almost straight; slight, broad oral concavity. Dorsal margin straight, sloping towards posterior: cardinal angles prominent. Valves with a sharp, very prominent, posterodorsal swelling just below cardinal angle. A deep, short, oblique sulcus just posterior to glassy, inconspicuous eye tubercle. Surface of valves ornamented by a series of ribs, intercostal areas smooth. Approximately 29 anterior and 24 posterior rpc; many bifurcate anteriorly, almost straight, medianly inflated, evenly spaced. Selvage strong, narrow, subperipheral. Hinge holamphidont. Central muscle scars comprise a single dorsal ovate adductor scar; median two scars and ventral scar divided; three ovate frontal scars in vertical row.

\section{Explanation of Plate 3.}

figs 1-6. Caudites sp. B: 1, LV, OS 16307 external lateral view $\times 63.9 ; \mathbf{2}, \mathbf{3}, \mathrm{RV}$, OS 16347 - 2, external lateral view $\times 63.9$, 3, detail of lateral ornament over central muscle scar area $\times 319.4 ; \mathbf{4}, \mathrm{LV}$, OS 16348 internal view $\times 65.1 ; \mathbf{5}$, AC, OS 16349 dorsal view $\times 73.1 ; \mathbf{6}$, RV, OS 16308 internal view $\times$ 63.5. figs 7-13. Mutilus dissimilis sp. nov.: 7, 13, RV, OS $16306-\mathbf{7}$, detail of central muscle scars $\times 188.1, \mathbf{1 3}$, internal view $\times 55.7$; 8, 9, Holotype LV, OS $16350-\mathbf{8}$, detail of normal pore $\times 1923.4$, 9, external lateral view $\times 50.8 ; \mathbf{1 0}$, Paratype RV, OS 16351 external lateral view $\times 50.8$; 11, LV, OS 16352 internal view $\times 50.8$; 12, Paratype AC, OS 16353 dorsal view $\times 54.7$. figs 14-21, 23, 24. Tenedocythere deltoides $($ Brady, 1890): 14, $\mathrm{CF}$, OS 16356 dorsal view $\times 53.4 ; \mathbf{1 5}$, CM, OS 16357 dorsal view $\times 59.3 ; \mathbf{1 6}$, LVM, OS 16358 external lateral view $\times 63.0 ; \mathbf{1 7}, \mathbf{2 0}$, RVF, OS 16359 $-\mathbf{1 7}$, external lateral view $\times 57.6$, 20, detail of central muscle scars $\times 246.6$; 18, A-1 LV, OS 16360 external lateral view $\times 68.1 ; 19$, RVM, OS 16361 external lateral view $\times 60.4 ; \mathbf{2 1}, \mathbf{2 3}, \mathbf{2 5}$, RVF, OS $16362-\mathbf{2 1}$, detail of central muscle scars $\times 208.2, \mathbf{2 3}$, internal view $\times 55.7, \mathbf{2 5}$, detail of hinge $\times 116.6 ; \mathbf{2 4}, \mathrm{RVM}, \mathrm{RT} / \mathrm{SIR} / 633$ internal view $\times 61.8$. figs 22, 26-32. Tenedocythere transoceanica (Teeter, 1975): 22, C, OS 16363 dorsal view $\times 54.2$; 26, 27, LV, OS $16364-\mathbf{2 6}$, external lateral view $\times 50.8, \mathbf{2 7}$, detail of lateral ornament $\times 246.1 ; \mathbf{2 8}, \mathrm{LV}$, OS 16365 internal view $\times 54.2 ; \mathbf{2 9}, \mathbf{3 1}$, RV, OS $16366-\mathbf{2 9}$, internal view $\times 50.8, \mathbf{3 1}$, detail of hinge $\times 142.2 ; \mathbf{3 0}, \mathrm{RV}$, OS 16367 external lateral view $\times 54.2 ; 32$, A-1 LV, OS 16368 external lateral view $\times 68.8$. 


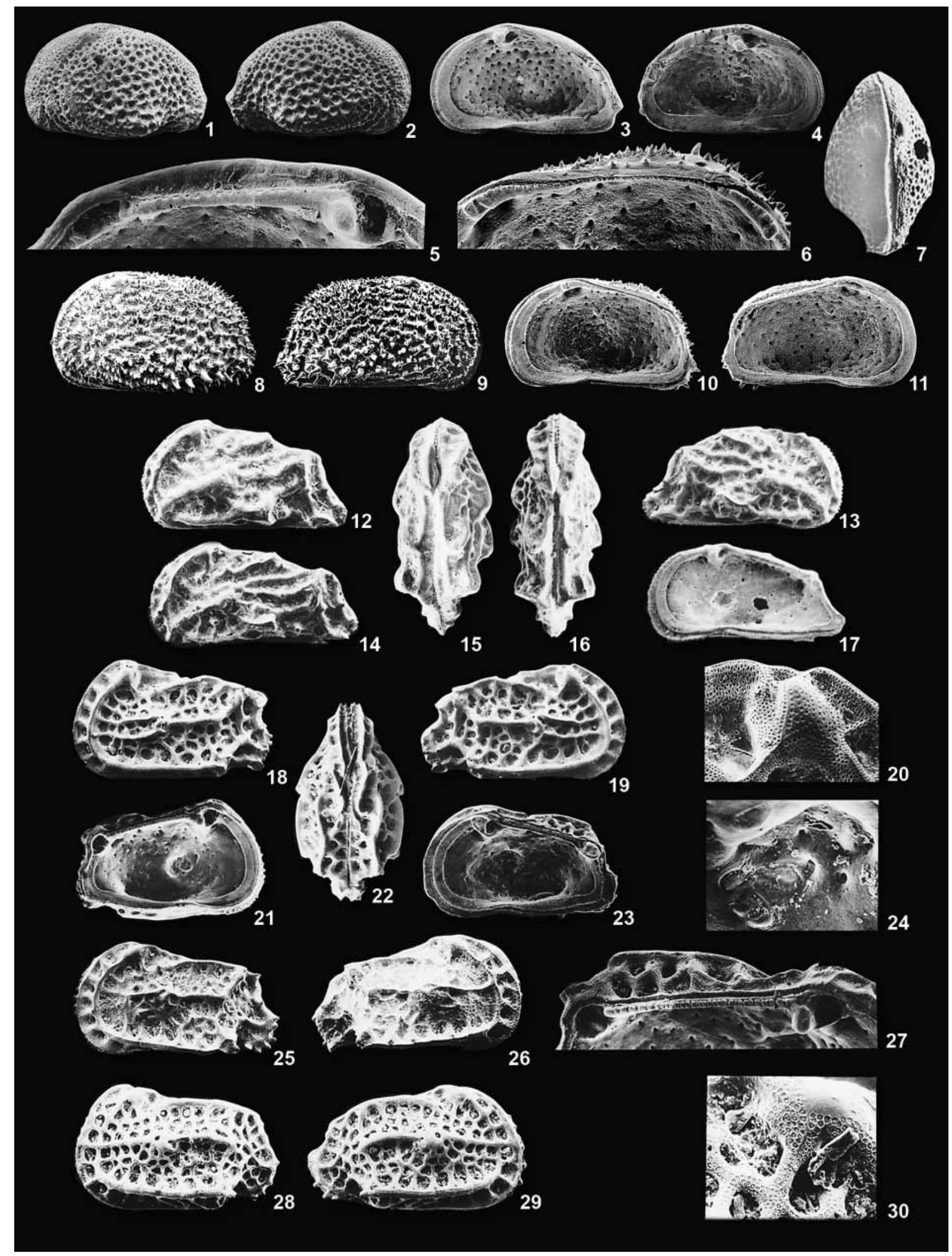


Dimensions.

$\begin{array}{llll} & \text { Length } & \text { Height } & \text { Width } \\ \text { C, OS 16345 } & 0.45 & 0.25 & 0.17 \\ \text { RV, OS 16344 } & 0.45 & 0.24 & \\ \text { LV, OS 16305 } & 0.46 & 0.25 & \\ \text { RV, RT/SIR/311 } & 0.46 & 0.24 & \end{array}$

Remarks. The present species is most similar to and is probably closely related to $C$. javana Kingma and Caudites sp. B, both of the present study. These species may be distinguished by the pattern of the ribs, particularly postero-laterally (see remarks for C. javana).

Caudites sp. B

(Fig. 4, nos 15, 16; P1. 3, figs 1-6)

Material. Four adult valves and one adult carapace. Samples: 1, 14, 40, Guadalcanal.

Description. Elongate, subtriangular in lateral view: hastate in dorsal view. Anterior margin broadly rounded. Posterior margin caudate; two backswept posteroventral marginal spines. Dorsal margin straight in male; gently arched in female; cardinal angles prominent. bearing. Short, oblique sulcus just posterior to glassy, inconspicuous eye tubercle. Surface of valves with broad smooth ribs, intercostal areas smooth or delicately but densely punctate. Npc moderately numerous, large, open, simple, some on pore conuli. Inner lamella broad with a narrow crescentic anterior and a small, irregular posterior vestibulum. Approximately 58 anterior and 39 posterior rpc, almost straight, fine, a few anteroventral canals bifurcate. Selvage strong, narrow, subperipheral. Hinge holamphidont. Central muscle scars small, ovate; dorsal and ventral adductor scars single; median scars divided; three ovate frontal scars in vertical row.

\section{Dimensions.}

$\begin{array}{lll} & \text { Length } & \text { Height } \\ \text { C, OS } 16349 & 0.52 & 0.27 \\ \text { LV, OS } 16307 & 0.54 & 0.30 \\ \text { RV, OS } 16347 & 0.53 & 0.30 \\ \text { LV, OS } 16348 & 0.53 & 0.30 \\ \text { RV, OS } 16308 & 0.52 & 0.28\end{array}$

Remarks. Caudites albatrossi Pokorny, 1970, from Recent sediments from the Galapagos Islands, is very similar to the present species. In both species the anterior ocular/anterior rib is interrupted anteroventrally but differs in the position of the posterior ribs. In $C$. albatrossi the rib extending ventrally from the postero-dorsal angle bifurcates; one branch anteriorly and the other continuing to the ventral margin; in the present species the posterior branch curves towards the posterior extremity. Caudites litusorienticola Hartmann (1981) from the subtropical east coast of Australia differs in possessing three approximately parallel ribs crossing the posterior half of the valve.

\section{Caudites sp. C}

(Fig. 4, no. 10; P1. 2, figs 26-31)

1988 Caudites litusorienticola Hartmann; Yassini \& Wright: 169, pl. 7, fig. H (non Hartmann, 1981).

1989a Caudites sp. Zhao \& Whatley: 186, pl. 4, fig. 14.

Material. One left valve and one carapace, both adult. Sample OS6 Shortland Island.

Description. Elongate subtriangular in lateral view: sub-elliptical in dorsal view. Anterior margin broadly rounded: extremity at mid-height. Posterior margin caudate. Dorsal margin very gently arched. Ventral margin almost straight. A deep short, oblique sulcus just posterior to small, glassy, inconspicuous eye tubercle. Surface of valves smooth with a series of weak, inconspicuous ribs. Npc moderately numerous, regularly distributed, large, simple open, pore conuli absent. Inner lamella moderately wide: a narrow, crescentic anterior vestibule and a small, irregular posterior vestibule. Approximately 40 anterior and 29 posterior rpc, simple, straight, a few anteroventral canals bifurcate. Selvage narrow, subperipheral. Hinge holamphidont. Central muscle scars small, ovate, situated in subcentral region; dorsal and median two adductor scars divided, single ventral scar; three frontal scars, median scar divided.

\section{Dimensions. \\ C, OS 16346 \\ LV, OS 16304 \\ Length
0.54 \\ 0.55 \\ Height \\ 0.29 \\ Width \\ 0.18}

Remarks. This species is described and illustrated incorrectly as Caudites litusorienticola Hartmann, 1981 by Yassini \& Wright (1988), from Port Hacking, New South Wales, Eastern Australia. Zhao \& Whatley (1989a) encountered just a few

Explanation of Plate 4.

figs 1-5, 7. Neobuntonia subalata sp. nov.: 1, Holotype LVF, OS 16369 external lateral view $\times 51.7$; 2, Paratype RVF, OS 16311 external lateral view $\times 53.6 ; 3$, Paratype RVF, OS 16370 internal view $\times 55.4 ; \mathbf{4}, \mathbf{5}$, Paratype LVF, OS $16371-\mathbf{4}$, internal view $\times 53.6,5$, detail of hinge $\times 69.1 ;$, CF, RT/SIR/333 dorsal view $\times 53.6$. figs 6, 8-11. Mimicocythere pseudomelobesoides sp. nov.: 6, 9, 10, Paratype RV, OS $16373-\mathbf{6}$, detail of hinge $\times 151.6,9$, external lateral view $\times 63.7, \mathbf{1 0}$, internal view $\times 60.8 ; \mathbf{8}$, Paratype LV, OS 16374 external lateral view $\times 66.0 ; 11$, Paratype LV, OS 16375 internal view $\times 60.8$. figs 12-17. ?Caudites atypicus sp. nov.: 12, Holotype LVF, OS 16377 external lateral view $\times 64.7$; 13, Paratype RVF, OS 16378 external lateral view $\times 60.4 ; \mathbf{1 4}$, Paratype LVM, OS 16379 external lateral view $\times 69.4 ; \mathbf{1 5}$, Paratype CF, OS 16380 dorsal view $\times 67.3$; 16, Paratype CM, OS 16381 dorsal view $\times 73.5 ; \mathbf{1 7}$, RVM, RT/SIR/349 internal view $\times 69.6$. figs 18-24, 27. Tenedocythere elongata $(\mathrm{Hu}, 1979): \mathbf{1 8}, \mathrm{LV}, \mathrm{OS} 16382$ external lateral view $\times 38.8 ; \mathbf{1 9}, \mathbf{2 0}, \mathrm{RV}$, OS $16383-\mathbf{1 9}$, external lateral view $\times 38.8, \mathbf{2 0}$, detail of lateral ornament over eye tubercle $\times 134.0 ; \mathbf{2 1}$, LV, OS 16316 internal view $\times 37.8$; 22, C, OS 16384 dorsal view $\times 37.6$; 23, RV, OS 16317 internal view $\times 37.8 ; \mathbf{2 4}$, 27, LV, OS $16385-\mathbf{2 4}$, detail of central muscle scars $\times 190.5, \mathbf{2 7}$, detail of hinge $\times 78.9$. figs 25, 26. Tenedocythere sp. A: 25, A-1 LV, OS 16386 external lateral view $\times 48.5 ; \mathbf{2 6}$, A-2 RV, OS 16387 external lateral view $\times 67.0$; figs 28-30. Tenedocythere sp. B: 28, A-1 LV, OS 16388 external lateral view $\times 55.0 ; 29, \mathbf{3 0}$, A-2 RV, OS $16389-\mathbf{2 9}$, external lateral view $\times 77.8, \mathbf{3 0}$, detail of lateral ornament over eye tubercle $\times 149.5$. 
specimens of the species from Jason Bay, SW Malay Peninsula. Caudites sanctaecrucis Pokorny, 1970, Recent, Galapagos Islands is also very weakly ornamented by ribs. The present species is ornamented even less strongly and possesses a short sulcus just posterior to the eye tubercle not present in $C$. sanctaecrucis and the dorsal rib does not curve along the entire dorsal margin as seen in the former. Caudites yambaensis Hartmann, 1981, Recent eulittoral, Eastern Australia, differs in that it possesses a short rib extending to the posterior extremity; this region of the caudal process is smooth in the present species. The two species are, however, very similar, as was also shown by the illustration of the former by McKenzie et al. (1990, pl. 6, fig. 2) from the Pleistocene of Goose Lagoon Drain, SE Australia. The prominent oblique lateral rib of Caudites propelevis Hartmann, 1981, also from the Recent eulittoral, Eastern Australia, distinguishes it from the present species. Caudites sublevis Bonaduce et al. (1980) from the Gulf of Aqaba is obviously of the same species group, but differs in its less arcuate dorsal margin and more numerous short horizontal ribs posterolaterally. The species described above is almost certainly new, but there are too few specimens to warrant the erection of a new species.

?Caudites atypicus sp. nov.

(Fig. 4, nos 20, 23; Pl. 4, figs 12-17)

Derivation of name. Greek $\tau v \pi \imath \kappa o \varsigma$ conformable, with the prefix $a$ to denote the reverse atypikos. With reference to the fact that this species resembles Caudites in all respects except for the absence of pillar structures in the inner lamella.

Diagnosis. A species questionably assigned to Caudites, with prominent swellings posterodorsally, posteroventrally and subcentrally. Surface ornament dominated by numerous lateral ribs radiating from subcentral tubercle, in particular two ribs to posterodorsal swelling with a third, short rib parallel to them, from the mid dorsal margin.

Holotype. Female LV, OS 16377.

Paratypes. Female C, OS 16380; Male C, OS 16381; Female RV, OS 16378; Male LV, OS 16379.

Material. 75 valves and carapaces, A-2 to adult. Samples: 1, 2, 5 , $14,15,17,19,29,30,32,40-42,54-57,60-62$, Guadalcanal.

Locality and horizon. Sample 29, $550 \mathrm{ft}$ offshore, west of Point Bay, Guadalcanal. 19 fathoms. Unconsolidated, coral sand. Recent.

Description. Small to medium. Thick-shelled, Opaque. Male less high and shorter than female. Subtriangular in lateral view: sub-elliptical in dorsal view. Anterior margin obliquely rounded, bearing numerous very small, frill-like marginal denticles which continue anteroventrally: extremity at mid-height. Posterior margin strongly caudate. Dorsal margin straight, inclined towards posterior, overhung by lateral tumidity to appear gently arched; cardinal angles acutely angled except anterior angle of
$\mathrm{RV}$ which is rounded. Ventral margin gently biconvex; frill-like marginal denticles except orally. Greatest length subventral, through posterior extremity; greatest height through anterior cardinal angle; greatest width through subcentral tubercle. LV $>$ RV, overlap at anterior cardinal angle. Valves swollen just below posterior cardinal angle, posteroventrally at two-thirds of the length and in area of subcentral tubercle. A strong ocular/ anterior marginal rib extends from anterior cardinal angle, with large glassy eye tubercle anterodorsally, parallels anterior and then becomes the ventro-lateral rib and terminating at the posteroventral swelling. A short rib bifurcates from the ocular rib to the anteroventral margin. A peripheral rib extends along the posterodorsal margin, sub-parallel to it a rib extends from the posterodorsal loop to the posteroventral angle. Lateral ornament dominated by ribs which radiate from the subcentral tubercle. A broad rib extends to anteroventral angle, crossing the ocular/anteromarginal rib; two parallel ribs extend to the posterodorsal loop with a third, shorter rib from the mid-dorsal margin that parallels these two ribs but does not reach the subcentral tubercle, and a short rib that extends vertically from the eye-tubercle towards the sub-central tubercle. Intercostal reticulation, variable in strength of development, but the muri are often strong and sharp posteriorly. Npc few, regularly distributed on ribs and muri of reticulation, usually as pore conuli, one conspicuous conulus midway along posterior peripheral rib. Inner lamella wide. Narrow crescentic anterior vestibule, elsewhere LOC and IM coincide, subparallel to OM. Approximately 42 anterior and 25 posterior rpc, slightly sinuous, most simple, some branching at caudal process. Strong selvage, becoming more peripheral posteriorly, particularly in LV: wide flange groove. Hinge holamphidont: RV anterior terminal element a strong tooth on wider platform; anteromedian element a deep socket bounded ventrally by an anti-slip bar; posteromedian element a long groove becoming locellate posteriorly to accommodate two denticles on LV hinge bar; posterior terminal element an elongate, irregular tooth. Central muscle scars not clear, small, ovate; four adductor scars in vertical row with at least one of the two central scars subdivided, two frontal scars.

$\begin{array}{llll}\text { Dimensions. } & & & \\ & \text { Length } & \text { Height } & \text { Width } \\ \text { Holotype Female LV, OS 16377 } & 0.51 & 0.28 & \\ \text { Paratype Female C, OS 16380 } & 0.52 & 0.28 & 0.23 \\ \text { Paratype Male C, OS 16381 } & 0.49 & 0.25 & 0.23 \\ \text { Paratype Female RV, OS 16378 } & 0.53 & 0.29 & \\ \text { Paratype Male LV, OS 16379 } & 0.49 & 0.25 & \\ \text { Male LV, OS 16312 } & 0.50 & 0.27 & \\ \text { Female RV, OS 16313 } & 0.50 & 0.25 & \\ \text { Male RV, RT/SIR/349 } & 0.46 & 0.24 & \end{array}$

Occurrence. This species is also common in Quaternary brackish-water sediments from the Indespensable Reefs and offshore, Quaternary marine sediments from Guadalcanal (Whatley et al., in press b).

Remarks. Caudites scopulicola Hartmann, 1981, Recent eulittoral of Eastern Australia, is remarkably similar but possesses cauditid pillar structures in its inner lamella, lacks the strong posteroventral swelling and also the strong median 
ventro-lateral rib. The present species differs from ?Caudites mcmillani Whatley \& Keeler, 1989 from the Recent of Réunion, which also lacks pillar structures in its inner lamella, in possessing three parallel, lateral ribs that extend obliquely from the posterodorsal margin, two to the subcentral tubercle. Another species they described, ?Caudites sp., also lacks pillars. It is, of course, possible that these three species could be considered as a new genus, based on the absence of the pillars. However, what was written then (Whatley \& Keeler, 1989: 70), still holds good today:

L'absence nette de cette structure dans les spécimens si bien conservés de notre étude suggère que leur absence n'est pas due à une destruction post-mortem. Les piliers sont également absents chez ?Caudites sp. Des espèces semblables provenant des Iles Solomon sont connues de l'un d'entre nous (R.W.) et il est possible qu'elles constituent un genre nouveau. L'absence de piliers nous conduit à attribuer avec doute le présente espèce au genre Caudites.

\section{Genus Mutilus Neviani, 1928}

Type species. Cythereis (Mutilus) laticancellata Neviani, 1928.

Remarks. Neviani (1928) erected Mutilus as a subgenus of Cythereis Jones, 1849. He included three species in the subgenus but, unfortunately, did not give comprehensive diagnoses. Ruggieri (1956) stated, however, that two of these species were not Mutilus and that the third C. (Mutilus) laticancellata Neviani, 1928 should, therefore, be the type species. Van Morkhoven (1963) believed that Mutilus comprises two subgenera; M. (Mutilus) and M. (Aurila) Pokorny, 1955, differing only in that the former possessed a stronger ornament. The present authors have followed the classification given in the Treatise on Invertebrate Paleontology and retained Mutilus and Aurila as separate genera. Both Mutilus and Aurila are characterized by the incised auriline posterior tooth of the RV hinge with a complementary tooth in the posterior socket of the LV. This structure distinguishes these two genera from some very similar taxa in such genera of the Thaerocytheridae as Quadracythere Hornibrook, 1952.

Mutilus dissimilis sp. nov.

(Fig. 4, nos 13, 14; Pl. 3, figs 7-13)

Derivation of name. Latin; with reference to the ornament of this species which is atypical of the genus.

Diagnosis. A species of Mutilus, characterized by its robust ornament of numerous lateral ribs with intercostal reticulae. Ornament dominated by an oblique, lateral rib extending over subcentral tubercle and a series of four ribs radiating from prominent, posterodorsal loop. Ribs form a conspicuous rightangled triangle just posterior to subcentral tubercle. Posterior terminal element of right valve hinge a long, slightly irregular incised tooth.

Holotype. LV, OS 16350.
Paratypes. RV, OS 16351; C, OS 16353; LV, OS 16354.

Material. 66 valves and carapaces, A-4 to adult. Samples: 1, 2, 13, 14, 29, 52, 55, 58, OS3, OS5, OS6, Guadalcanal and Shortland islands.

Locality and horizon. Sample OS5, coral reefs to the east of Rokuai Island, off the northeast coast of Shortland Island. Coarse-grained coral sand. Recent.

Description. Medium. Thick-shelled. Opaque. Subquadrate to subovate in lateral view; irregularly spindle-shaped in dorsal view. Sexual dimorphism inconspicuous. Anterior margin broadly rounded: extremity below mid-height. Posterior margin bluntly caudate; a concave posterodorsal slope and a convex posteroventral slope. Dorsal margin very gently convex, slightly sloping, overhung posteriorly by lateral ornament; anterior cardinal angle rounded; posterior angle more pronounced. Ventral margin gently biconvex. Greatest length through posterior extremity, well below mid-height; greatest height through anterior cardinal angle; greatest width through posterolateral tumidity. LV $>\mathrm{RV}$, overlaps along dorsal and anterodorsal margins. Strongly ornamented by numerous ribs and intercostal reticulae. Distinct, strong, subperipheral, ocular antero-marginal rib begins just dorsal to glassy eye-tubercle, parallels anterior margin and then becomes the ventro-lateral rib. A series of ribs radiate from postero-dorsal loop over the posterior cardinal angle. A prominent rib extends obliquely anteriorly to an area below eye tubercle, a second rib branches vertically from posterior end of first rib to mid-height where it almost undergoes a right angle to continue anteriorly, subparallel to the first rib. From this right angle of the second rib a short rib continues ventrally, then anteriorly joining the second rib again at the subcentral tubercle, forming a small right-angled triangle. A third, gently curved rib extends ventrally from the posterodorsal inflation, then posteriorly to meet the margin just below posterior extremity. A fourth, more posterior rib is subparallel to the third, meeting the margin at the posterior extremity. A strong ventrolateral rib develops into a small ala posteroventrally and continues as a weaker rib to posterior margin. Strong intercostal reticulae link the ribs, with secondary ornamentation of very fine etching on muri of primary reticula; less dense in fossea. Npc moderately numerous, large, sieve type, evenly distributed mainly on muri, some on pore conuli, particularly posteriorly. Inner lamella moderately wide: LOC and IM coincident, subparallel to OM. Rpc numerous: 63-65 anterior and 56-59 posterior canals; slightly sinuous, simple, closely spaced except in oral concavity, slightly inflated medianly. Selvage robust, subperipheral in RV; more distal in LV. Hinge holamphidont, very robust: RV anterior terminal element a strong ovate tooth vertically aligned; anteromedian element a deep smooth socket bounded ventrally by an anti-slip bar; posteromedian element a long, smooth groove; posterior terminal element a long, slightly irregular incised tooth; LV complementary. Central muscle scars small, ovate; median two adductor scars divided, dorsal and ventral sears single, two ovate frontal scars. 
Dimensions.

$\begin{array}{llll} & \text { Length } & \text { Height } & \text { Width } \\ \text { Holotype LV, OS 16350 } & 0.63 & 0.39 & \\ \text { Paratype C, OS 16353 } & 0.64 & 0.37 & 0.36 \\ \text { Paratype RV, OS 16351 } & 0.65 & 0.39 & \\ \text { Paratype LV, OS 16354 } & 0.62 & 0.39 & \\ \text { LV, OS 16352 } & 0.64 & 0.40 & \\ \text { RV, OS 16306 } & 0.61 & 0.36 & \\ \text { A-1 LV, OS 16355 } & 0.51 & 0.35 & \end{array}$

Remarks. The present species differs M. splendideornatus australiensis Hartmann, 1978, Recent eulittoral of Western Australia, in the pattern of the lateral ribs and detail of the lateral ornament, just posterior of the centre. Mutilus sp. illustrated by Jain (1978), from the Recent off Western India has less strongly developed lateral ribs. Mutilus (M.) oahueneis Holden, 1967, from the Neogene of Hawaii is about $0.2 \mathrm{~mm}$ longer, less inflated posterodorsally and differs in the detail of the reticulate ornament. Mutilus sp. described by Hartmann (1981) from the Recent eulittoral of NE Australia, differs in the detail of the surface ornament, particularly below the eye tubercle. Mutilus curvicostatus Howe \& McKenzie, 1989 from Northern Australia, is obviously closely related, with its numerous ribs and the nature of its intercostal reticulation but differs significantly in the detail of the ornament. A remarkably similar species in shape, outline and ornament is Tenedocythere keralaensis Khosla \& Nagori, 1989, Lower Miocene of South India, but it lacks auriline dentition. The presence of sexual dimorphism may be indicated by the large range in width of adults. A specimen confidently considered a male LV (OS 16354) can be compared with the female left valve (OS 16350); others range in morphology between these two extremes.

\section{Genus Mimicocythere gen. nov.}

Derivation of name. Latin, mimus (Greek $\mu \iota^{-} \mu o \varsigma$ ) an imitator or mimic. With reference to the way in which this genus mimics such unrelated genera as Echinocythereis Puri, 1953 and Henryhowella Puri, 1957a.

Type species. Mimicocythere pseudomelobesoides gen. et sp. nov.

Remarks. For a diagnosis and description, see the type species. This genus has caused considerable confusion. It seems to be monotypic and to be confined to Australasia and the Solomon Islands. The genus is very difficult to classify since it has many enigmatic characters. For example, it is close in its overall carapace morphology to Cythere melobesoides Brady, 1869. However, as originally pointed out by Dingle et al. (1990), Brady may have combined two species. He initially (1869) recorded $C$. melobesoides from Mauritius but, in 1880, he recorded it from off the Cape Peninsula of South Africa in some $275 \mathrm{~m}$ of water and from Australia. Dingle et al. (1990) stated that their material, from deep-water Quaternary deposits off SW Africa, is conspecific with that illustrated from Brady's Challenger collections by Puri \& Hulings (1976, pl. 25, figs 1, 2) from which a lectotype was erected and it is agreed that this material is conspecific with the material illustrated by Brady (1880, pl. 12, figs 10, 11). The Australian material illustrated by Brady (1880, pl. 18, figs 1a-d) in some ways resembles the present species, especially in the rather truncated posterior margin, but $(\mathrm{L}=0.75 \mathrm{~mm})$ is much larger and, although not conspecific with the African and Indian Ocean material, it is equally not the present species. The original Australian material in the Natural History Museum, London remains unstudied; however, it seems to be conspecific with that described by Howe $\&$ McKenzie (1989) from specimens in the Northern Territory Museum, in which an adult male is recorded as $\mathrm{L}=0.70 \mathrm{~mm}$. These latter authors unfortunately, however, record neither the hingement nor the musculature of this collection, and its exact provenance is not given.

Mimicocythere differs from Cythere melobesoides s.1. in two important ways: first it has antimerodont rather than holamphidont hingement and, secondly, the second most dorsal of its adductor scars is clearly subdivided and it has two discrete oval frontal scars, while the latter species has four undivided adductors and a v-shaped frontal scar. It is also notably smaller, being approximately $0.50 \mathrm{~mm}$ long. Given its small size and its merodont hinge, the authors were initially tempted to consider even the largest individuals as juveniles, perhaps A-2 or A-3 juveniles of Henryhowella melobesoides (Brady). However, it is clear from the width and advanced nature of the inner lamella as illustrated herein, that the type species of Mimicocythere is certainly adult in character.

\section{Mimicocythere pseudomelobesoides sp. nov.} (Pl. 4, figs 6, 8-11)

1987 Echinocythereis melobesoides (Brady); Yassini \& Jones: 823, figs 3.15, 3.16 (non Cythere melobesoides Brady, 1869).

1988 Echinocythereis melobesoides (Brady); Yassini \& Wright: 169 , figs $6 \mathrm{~A}, \mathrm{~B}$.

1995 Echinocythereis cf. melobesoides (Brady); Yassini \& Jones: 356, figs 412, 414.

2006 Echinocythereis sp., Warne et al.: 152, pl. 8, fig. 16. non 1880 Cythere melobesoides Brady; Brady: 108, pl. 18, fig. 1e-g [=Henryhowella melobesoides (ex Cythere melobesoides Brady, 1869)].

Derivation of name. Latin; from the close, but entirely superficial resemblance, of this species to the largely South African trachyleberid species Henryhowella melobesoides (Brady, 1869).

Diagnosis. A small to medium spinose species of Mimicocythere with antimerodont dentition.

Holotype. LV, OS 16376.

Paratypes. RV, OS 16373; LV, OS 16374; LV, OS 16375.

Material. Four adult valves. Sample: 14, Guadalcanal.

Locality and horizon. Sample 14, $1400 \mathrm{ft}$ offshore, west of Point Cruz, Honiara Bay, Guadalcanal. 10 fathoms. Unconsolidated, medium-grained coral sand. Recent.

Description. Small to medium. Thick-shelled and opaque. Subrectangular to subovate to subrhomboidal, especially in $\mathrm{RV}$, in lateral view. Anterior margin broadly rounded, especially in RV; 
extremity at mid-height. Posterior margin blunter and subcaudate in RV, especially males; extremity below mid-height to sub-ventral in male RV and bearing strong marginal denticles. Dorsal margin straight to very gently convex and overhung in lateral view by dorso-lateral margin; sloping posteriorly. Ventral margin almost straight. Valves inflated posteroventrally. Eye tubercle small but conspicuous. Surface ornament strongly spinose. Rows of large and markedly smaller spines seem to be superimposed on the muri of a fundamental reticulation. The overall disposition of the rows of spines is approximately concentric about mid-point. Npc fairly numerous, simple but with some sieve-type pores in solae. Many large and some small spines are perforate. Inner lamella of medium width; avestibulate. Npc not seen. Hinge antimerodont: RV anterior terminal element a dentate ridge in which the seven teeth decline in size and height from the anterior; posterior similar but with nine or ten teeth, median element a rather coarsely locellate groove. Adductor scars a vertical row of four with the second scar being clearly subdivided. There are two oval frontal scars. There is a very deep ocular sinus under the anterior terminal hinge element.

\section{Dimensions.}

Holotype LV, OS 16376

Paratype RV, OS 16373

Paratype LV, OS 16374

Paratype LV, OS 16375

Length
0.48
0.51
0.50
0.51

Height

0.28

0.28

0.29

0.28

The type material of Warne et al., 2006 from Port Darwin is of very similar size:

$\begin{array}{lll} & \text { Length } & \text { Height } \\ \text { LV, BB/NA 241 } & 0.46 & 0.26 \\ \text { LV, BB/NA 242 } & 0.50 & 0.30\end{array}$

Occurrence. The species has also been recorded from the area of Port Darwin, Northern Australia (Warne et al., 2006) and eastern Australia by Yassini and co-workers (see synonymy).

Remarks. Externally the present species is somewhat similar to Echinocythereis scabra (Münster) 1830, but can be distinguished from it by its more subovate outline and by the orientation of the spinose ornament. Neobuntonia subulosa (Brady), 1880 and $N$. subalata sp. nov. are also slightly similar but can be distinguished from the present species by their shape and lack of a strongly spinose ornament. In their record of Echinocythereis melobesoides (Brady), Howe \& McKenzie (1989: 40, figs 134, 135) made mention of A-1 juveniles and it would be interesting to see if these were similar to the present material. Although only four specimens were found in the present material, enough occur in other collections to justify the erection of a new taxon. For example, there are three adult LV in the Natural History Museum, London from the type collection of the paper by Warne et al. (2006) and the material described by Yassini and his co-workers (see synonymy).

Subfamily Thaerocytheridae Hazel, 1967 Genus Neobuntonia Hartmann, 1981

Type species. Neobuntonia sierbertorum Hartmann, 1981.
Remarks. It is very difficult to classify this genus correctly as all too little is known about it because this is only the second modern species of the genus, which was originally established solely on three specimens. However, on the basis of its musculature, it is for the present placed temporarily in the Thaerocytheridae, notwithstanding Jellinek's (1993: 136) interesting discussion. The central muscle scars observed in the present species comprise four adductors, ovate except for the ventromedian scar which is more elongate, and two small, ovate frontal scars, vertically aligned. A small, prominent fulcral point is present between dorsomedian adductor and dorsal frontal scar.

Neobuntonia subalata sp. nov.

$$
\text { (Pl. 4, figs 1-5, 7) }
$$

Derivation of name. Latin; with reference to the small, blunt, alar process of this species.

Diagnosis. A species of Neobuntonia with a small, blunt alar process and characterized by its reticulato/punctata ornament, concentric about mid-point; the fossae being largest subcentrally, decreasing in size distally and becoming very small peripherally. Numerous conjunctive normal pores. Secondary ornament of fine papillae within primary fossae.

Holotype. Female LV, OS 16369.

Paratypes. Female RV, OS 16311; Female RV, OS 16370; Female LV, OS 16371; Male LV, RT/SIR/338.

Material. Sixteen valves and carapaces, A-2 to adult. Samples: 40, OS5, OS6, Guadalcanal and Shortland islands.

Locality and horizon. Sample OS5, coral reefs to the east of Rokuai Island, off the northeast coast of Shortland Island. Coarse-grained coral sand. Recent.

Description. Medium. Thick-shelled. Opaque. Male smaller and less inflated than female. Sub-triangular in lateral view, spindleshaped in dorsal view. Anterior margin broadly rounded: extremity below mid-height. Posterior margin bluntly caudate; posterodorsal slope concave meeting straight, oblique posteroventral slope at a right angle. Dorsal margin arched, sloping posteriorly; anterior cardinal angle of $\mathrm{RV}$ is more pronounced. Greatest length well below mid-height, greatest height through anterior cardinal angle; greatest width at posterior third. LV > RV, overlap on dorsal margin. Eye-spot large, conspicuous, ovate, just below anterior cardinal angle. Valves strongly inflated posteroventrally, becoming almost alate. Surface of valves reticulato/punctata. Reticulae subovate, concentric around mid-point, largest subcentrally, decreasing in size distally and becoming minute puncta peripherally. Small conjunctive spines developed in posterior region. Secondary ornament of fine papillae within some fossae. Npc numerous, large, simple, regularly distributed and mainly conjunctive. Inner lamella moderately wide; avestibulate. Approximately 30 anterior and 15 posterior rpc, simple, almost straight, one or two false canals anterodorsally. Hinge holamphidont: RV anterior terminal element a strong, ovate boss with a row of three small teeth along 
dorsal edge; anteromedian element a deep, two-stepped socket; posteromedian element a long groove with locules developed along dorsal edge; posterior terminal element a rectangular tooth; LV complementary. Central muscle scars comprise four adductors, ovate except ventromedian scar that is elongate and two small, ovate frontal scars vertically aligned, small, prominent, ovate fulcral point between dorsomedian adductor and dorsal frontal scar.

\section{Dimensions.}

Holotype Female LV, OS 16369

Paratype Female RV, OS 16311

Paratype Female RV, OS 16370

Paratype Female LV, OS 16371

Female C, RT/SIR/333

A-1 LV, OS 16372

Length
0.58
0.56
0.56
0.56
0.53
0.45

$\begin{array}{ll}\text { Height } & \text { Width } \\ 0.35 & \\ 0.33 & \\ 0.34 & \\ 0.34 & \\ 0.30 & 0.30 \\ 0.28 & \end{array}$

Remarks. The type species, $N$. siebertorum Hartmann, 1981 from the Recent eulittoral of NE Australia is less densely and finely reticulate, particularly towards the margins and is less strongly alate postero-ventrally. Several species of Pokornyella Oertli, 1956 externally resemble the present species. Pokornyella pseudojaponica Holden, 1976, from the Miocene of Midway Island, possesses larger fossae anteromarginally as does $P$. japonica Ishizaki, 1968, from the Recent off Japan. Pokornyella deformis (Reuss), 1850 of Holden, 1976, from the Miocene of Midway Island lacks the broad antero-marginal area of fine reticulae. Pokornyella sp. 1 McKenzie, 1974, from the Recent off Southern Australia, possesses a reticulate ornament that is strongly aligned longitudinally.

\section{Genus Tenedocythere Sissingh, 1972}

Type species. Cythere prava Baird, 1850.

Remarks. Quadracythere Hornibrook, 1952 and Tenedocythere are regarded here as closely related genera differentiated by the presence of strong ribs in the latter which are absent in the former. Bosasella Bonaduce, 1985 is considered a junior synonym of Tenedocythere, which is where Neohornibrookella and Paraquadracythere, both Jellinek, 1993, should also be subsumed. The exact nature of the relationship of Jugosocythereis Puri, 1957b to this group remains unknown but this latter genus does not seem to be a true thaerocytherid since two of its adductor scars are divided.

Tenedocythere deltoides (Brady, 1890)

(Fig. 4, nos 17, 18; Pl. 3, figs 14-21, 23, 24)

1890 Cythere deltoides Brady: 501, pl. 2, figs 17, 18.

1978 Quadracythere fabianae Bonaduce et al.: 382, pl. 5, figs 3-6. 1980 Quadracythere fabianae Bonaduce et al.; Bonaduce et al.: pl. 5, figs 8, 9.

1981 Radimella parviloba $\mathrm{Hu}$ : 89, pl. 1, figs 1, 3, 5, 7; t-fig. 8 a-b. 1981 Quadracythere sp. Hartmann (pars): 109, pl. 6, fig. 3.

1982 Schizocythere parviloba $(\mathrm{Hu})$; Hu: 185, pl. 4, figs 13, 16-18; t-fig. 7.

1984 Quadracythere insulardeaensis Hartmann (pars): 126, pl. 2, figs 8, 9 (non figs 1-4).
1984 Quadracythere sp. Hartmann: 127, pl. 5, figs 10, 11.

1986 Tenedocythere deltoides (Brady); McKenzie: pl. 1, fig. 22. 1988 Hermanites parviloba $(\mathrm{Hu})$; Cronin: pl. 1, fig. 9.

1989 Quadracythere (Tenedocythere) deltoides (Brady); Whatley

\& Keeler: 78, pl. 5, figs 8-10.

1993 Paraquadracythere deltoides (Brady); Jellinek: 155, pl. 28, figs $444-456$.

Material. 134 valves and carapaces, A-5 to adult. Samples: 1, Honiara Bay and OS5, OS6, Shortland Island.

\section{Dimensions.}

Female C, OS 16356

Female RV, OS 16359

Male LV, OS 16358

Male LV, RT/SIR/633

Female RV, OS 16362

Male RV, OS 16361

Male C, OS 16357

Female RV, OS 16310

Male LV, OS 16309

A-1 LV, OS 16360

$\begin{array}{ll}\text { Length } & \text { Height } \\ 0.59 & 0.36 \\ 0.59 & 0.33 \\ 0.54 & 0.32 \\ 0.55 & 0.32 \\ 0.61 & 0.36 \\ 0.53 & 0.32 \\ 0.54 & 0.30 \\ 0.59 & 0.33 \\ 0.54 & 0.32 \\ 0.47 & 0.28\end{array}$

Width 0.35

Occurrence. This widespread Indo-Pacific species also occurs in Quaternary deposits from the Solomon Islands (Whatley et al., in press a) and among Recent sediments sent to the authors by Dr Maddocks from Madagascar, although she did not describe it there herself.

Remarks. Tenedocythere apios (Whatley et al., in press a) from the Pitcairn group is probably closest in shape to $T$. deltoides but the former has much more robust ornament and a more pronounced caudal process.

Tenedocythere transoceanica (Teeter, 1975)

(Fig. 4, nos 21, 22; P1. 3, figs 22, 26-32)

1975 Hermanites transoceanica Teeter: 450, pl. 11, figs o-q; pl. 12, fig. h.

1995 Tenedocythere transoceanica (Teeter); Whatley \& Roberts: 362, pl. 1, fig. 15 (q.v. for synonymy).

1995 Tenedocythere transoceanica (Teeter); Tabuki \& Nohara: 346 , figs $4,9$.

2008 Tenedocythere transoceanica (Teeter); Whatley et al.

Material. 207 valves and carapaces, A-2 to adult. Samples: 1, 2, 5, 13-15, 17, 19, 20, 29, 30, OS6, Guadalcanal and Shortland islands.

Dimensions.

$\begin{array}{llll} & \text { Length } & \text { Height } & \text { Width } \\ \text { RV, OS 16364 } & 0.63 & 0.34 & \\ \text { C, OS 16363 } & 0.59 & 0.34 & 0.41 \\ \text { RV, OS 16366 } & 0.63 & 0.34 & \\ \text { LV, OS 16365 } & 0.60 & 0.34 & \\ \text { RV, OS 16315 } & 0.63 & 0.33 & \\ \text { LV, OS 16314 } & 0.62 & 0.36 & \\ \text { A-1 LV, OS 16368 } & 0.48 & 0.28 & \end{array}$

Occurrence. It is not surprising to find this almost ubiquitous (except for the Atlantic) tropical species in the Solomon Islands. 
It also occurs in Quaternary sediments off Guadalcanal and in the Indispensable Reefs (Whatley et al., in press b). Recent new records are Whatley \& Roberts (1995) and Whatley et al. (in press b) from the Pitcairn Island group. It is notably absent from Easter Island, probably because of its too southerly situation (Whatley \& Jones, 1999; Whatley, 2000; Whatley et al., 2000).

Remarks. Juveniles of this species tend to resemble adults of Tenedocythere deltoides. Jellinek (1993) considered this species to be conspecific with Cythere lactea Brady, 1886. However, $C$. lactea is based on a single specimen (discounting the variety rudis) and neither of these seem in Brady's original illustrations to resemble $T$. transoceanica and the same can be said for Brady's (1880) illustration of C. lactea in the Challenger material.

Tenedocythere elongata ( $\mathrm{Hu}, 1979)$

(Fig. 4, nos 24, 25; P1. 4, figs 18-24, 27)

1966 Genus Uncertain species HA Maddocks: 57; fig. 38-1.

1972 Jugosocythereis sp. Benson: 124, pl. 8, fig.1.

1975 Bradleya sp. Liebau: 370.

1977 MS Bradleya sp. Hughes: pl. 70, fig.16.

1979 Radimella elongata Hu: 63, pl. 1, figs 11, 12

1981 Radimella macroloba $\mathrm{Hu}$ : 88, pl. 1, figs 2, 8, 18.

1981 Radimella macroloba $\mathrm{Hu}$; Hu: 189, pl. 4, figs, 23, 25, 27, 28.

1988 Radimella macroloba $\mathrm{Hu}$; Zhao \& Wang: 816, pl. 2, fig. 29.

1990 Bradleya elongata (Hu); Gou: 28, pl. 2, fig. 25.

1993 Bosasella elongata (Hu); Jellinek: 148, pl. 24, figs 391-398.

Material. 390 valves and carapaces, A-4 to adult. Samples: 2, Honiara Bay and OS6, Shortland Island.

Dimensions.

$\begin{array}{llll} & \text { Length } & \text { Height } & \text { Width } \\ \text { AC, OS 16384 } & 0.85 & 0.48 & 0.47 \\ \text { LV, OS 16382 } & 0.85 & 0.50 & \\ \text { RV, OS 16383 } & 0.85 & 0.47 & \\ \text { RV, OS 16317 } & 0.82 & 0.49 & \\ \text { LV, OS 16385 } & 0.84 & 0.50 & \\ \text { LV, OS 16316 } & 0.82 & 0.51 & \\ \text { A-1 RV, OS 16386 } & 0.68 & 0.39 & \end{array}$

Occurrence. As its synonymy shows, this is a very common and widespread species in the Indo-Pacific. In the Solomon Islands it was encountered by Hughes (1977 MS) in Miocene deposits from Nendö on Guadalcanal and in the Quaternary of the Indispensable Reefs and offshore Guadalcanal (Whatley et al., in press a).

Remarks. The present material is rather less punctate on the crests of the major ribs than in most populations.

\section{Tenedocythere sp. A \\ (P1. 4, figs 25, 26)}

Diagnosis. A large species of Tenedocythere characterized by its costate and minutely reticulate surface ornament.

Material. Thirteen juvenile valves, A-1 to A-3 instars. Samples: 14, 29, Guadalcanal.
Dimensions.

A-1 LV, OS 16386

A-2 RV, OS 16387
Length
0.68

0.50

0.37

0.28
Height

Occurrence. Over 600 valves and carapaces were found in Quaternary shallow-water marine sediments from offshore Guadalcanal by Williams (1980 MS). This will be described as a new species by Whatley et al. (in press a).

\section{Tenedocythere sp. B \\ (P1. 4, figs 28-30)}

Diagnosis. A large subquadrate to subrectangular species of Tenedocythere with strong ribs and strong intercostal reticulation, the muri of which are strongly punctate, each puncta bearing a small, central papilla.

Material. Thirteen juvenile valves. Samples: 14, 29, 30, 52, 40, 41, 54, 55, 60, Guadalcanal.

\section{Dimensions.}

A-1 LV, OS 16388

A-2 RV, OS 16389

Length
0.60
0.45

Height

0.36

Occurrence. This species is fairly common in Quaternary sediments from the Indispensable Reefs and offshore Guadalcanal (Williams, $1980 \mathrm{MS}$ ). It will be described as a new species shortly (Whatley et al.,in press a).

\section{ACKNOWLEDGEMENTS}

The authors thank Eden Fundingsland for creating the plates and figures and her assistance in their design and layout. The support provided by Statoil ASA, Stavanger is also acknowledged. The samples were kindly made available by Wynn Hughes and Colin Turner. The sincere thanks of RT to Giles Miller at the British Museum for his cheerful assistance while allocating numbers to the specimens. Thanks must also go to the reviewers for critically evaluating the original submission.

\section{Manuscript received 27 December 2005 Manuscript accepted 26 June 2007}

\section{REFERENCES}

Baird, W. 1850. Description of several new species of Entomostraca. Proceedings of the Zoological Society, 18: 254-257.

Benson, R.H. 1972. The Bradleya problem, with descriptions of two new psychrospheric ostracode Agrenocythere and Poseidonamicus (Ostracoda: Crustacea). Smithsonian Contributions to Palaeobiology, 33 (1-3): 1-138.

Bonaduce, G. 1985. Bosasella, a new marine ostracode genus from Somalia. Bolletino Societe Naturali di Napoli, 40 (1): 3-11.

Bonaduce, G., Masoli, M. \& Pugliese, N. 1978. Benthic Ostracoda from the Gulf of Aquaba. Pubblicazione Stazzione Zoologico di Napoli, 41 (2): $372-428$.

Bonaduce, G., Masoli, M., Minichelli, G. \& Pugliese, N. 1980. Some new benthic marine ostracod species from the Gulf of Aqaba (Red Sea). Bolletino Societe Paleontologico Italiana, 19 (1): 143-178.

Brady, G.S. 1866. On new or imperfectly known species of marina Ostracoda. Transactions of the Zoological Society of London, 5 (5): 359-393. 
Brady, G.S. 1869. Les entomostraces de Hong Kong. In: Folin, A.G.L. \& Périer, L. (Eds), Les Fonds de la Mer, 1(1). Savy, Paris, 155-159.

Brady, G.S. 1880. Report on the Ostracoda. Report of the Scientific Results of the Voyage of H.M.S. Challenger, 1873-1886. Zoology, 1(3): $184 \mathrm{pp}$.

Brady, G.S. 1890. On Ostracoda collected by H. B. Brady, Esq. L.L.D., F.R.S., in the South Sea Islands. Transactions of the Royal Society of Edinburgh, 35: 489-525.

Cabioch, G., Anglada, R. \& Babinot, J.F. 1986. Microfaunas et paléoenvironments des récifs frangeants quatenaires de mamie et Ricaudy (Nouvelle-Calédonie). Cahairs de Micropaléontologie, n.s., 1 $(1 / 2): 5-36$.

Coryell, H.N. \& Fields, S. 1937. A Gatun ostracode fauna from Cativa, Panama. American Museum Novitates, 956: 1-18.

Cronin, T.M. 1988. Geographical isolation in marine species: evolution and speciation in Ostracoda, 1. In: Hanai, T., Ikeya, N. \& Ishizaki, K. (Eds), Evolutionary biology of Ostracoda, its fundamentals and applications. Proceedings of the 9th International Symposium on Ostracoda. Shizuoka, Japan, 1985. Developments in Palaeontology and Stratigraphy, 11. Kodansha/Elsevier, Oxford, 871-889.

Dingle, R.V., Lord, A.R. \& Boomer, I.D. 1990. Deep-water Quaternary Ostracoda from the continental margin off south-western Africa (SE Atlantic Ocean). Annals of the South African Museum, 99 (9): 245-366.

Gou, Y. 1990. Recent Ostracoda from Hainan island, South China Sea. Courier Forschungs-Institut Senckenberg, 123: 19-36.

Guha, D. 1968. On the Ostracoda from Neogene of Andaman Islands. Journal of the Geological Society of India, 2: 208-217.

Harding, J.P. 1962. Mungava munda and four other new species of ostracod crustaceans from fish stomachs. Natural History of Rennel Island, British Solomon Islands, Copenhagen, 4: 51-62.

Hartmann, G. 1959. Zur Kenntnis der lotischen Lebensbereiche der pazifischen Kuste von El Salvador unter besonderer Berücksichitung seiner Ostracodenfauna (III Beitrag zur fauna El Salvadors). Keiler Meeresforschungen, 15 (2): 27-48.

Hartmann, G. 1962. Ostracoden des Eulittorals. In: HartmannSchroder, G. \& Hartmann, G. (Eds), Zur Kenntnis des Eulittorals der chilenischen Pakifikküsten und der Küsten Sud patagoniens - unter besonderer Berücksichitung der Polychaeten und Ostracoden. Mitteilungen aus den Hamburgischen Zoologischen Museum und Institut, 60: 169-265.

Hartmann, G. 1978. Die Ostracoden der Ordnung Podocopida G. W. Müller, 1894 der tropisch-subtropischen Westküste Australiens (zwischen Derby im Norden und Perth im Süden). In: Hartmann-Schroder, G. \& Hartmann, G. (Eds), Zur Kenntnis des Eulittorals der australischen Küsten unter besonderer Berücksichitung der Polychaeten und Ostracoden. Teil 1. Mitteilungen aus den Hamburgischen Zoologischen Museum und Institut, 75: 63-219.

Hartmann, G. 1981. Die Ostracoden der Ordnung Podocopida G. W Müller, 1894 der subtropisch-tropischen ostküste Australiens (zwischen Eden in süden und Heron-Island im norden). Mitteilungen aus den Hamburgischen Zoologischen Museum und Institut, 78: 97-149.

Hartmann, G. 1984. Zur Kenntnis der Ostracoden der polynesischen Inseln Huahine (Gesellschaftsinseln) und Rangiroa (Tuamotu-Inseln). Mitteilungen aus den Hamburgischen Zoologischen Museum und Institut, 81: 117-169.

Hartmann, G. \& Kuhl, C. 1978. Zur variabilitat der Oberflachenornamente der schalen lebender ostracoden-populationen. Mitteilungen aus den Hamburgischen Zoologischen Museum und Institut, 75: 221-223.

Hazel, J.E. 1962. Two new hemicytherid ostracods from the Lower Pleistocene of California. Journal of Paleontology, 36 (4): $822-826$.

Hazel, J.E. 1967. Classification and distribution of the Recent Hemicytheridae and Trachyleberididae (Ostracoda) off northeastern North America. United States Geological Survey, Professional Paper, 564: $1-49$.

Holden, J.C. 1967. Late Cenozoic ostracodes from the drowned terraces in the Hawaiian Islands. Pacific Science, 21 (1): 1-50.

Holden, J.C. 1976. Late Cenozoic Ostracoda from Midway Island Drill Holes. United States Geological Survey, Professional Paper, 680-F: 40pp.
Hornibrook, N. de B. 1952. Tertiary and Recent marine Ostracoda of New Zealand. Their origin, affinities and distribution. Palaeontological Bulletins, New Zealand Geological Survey, 18: 1-82.

Howe, H.V. \& McKenzie, K.G. 1989. Recent marine Ostracoda (Crustacea) from Darwin and North Western Australia. Northern Territory Museum of Arts and Sciences, Monograph Series, 3: 1-50.

Hu, C.H. 1979. Studies on ostracode faunas from the Hengchun Formation, Hengchun Peninsula, southern Taiwan. Petroleum Geology of Taiwan, 16: 59-84.

Hu, C.H. 1981. New ostracod faunas from the Maanshan Mudstone of Hengchun Peninsula, southern Taiwan. Journal of the Taiwan Museum, 2(1.2): 65-130.

$\mathrm{Hu}$, C.H. 1982. Studies on ostracode faunas from the Hengchun Limestone. In: Bate, R.H., Robinson, E. \& Sheppard, L.M. (Eds), Fossil and Recent Ostracods. Ellis Horwood for the British Micropalaeontological Society, Chichester, 381-405.

Hughes, G.W. 1977. MS. The Geology and foraminiferal Micropalaeontology of the Lungga and Itina Basin areas of Western Guadalcanal, Solomon Islands. Unpublished $\mathrm{PhD}$ thesis. University of Wales, Aberystwyth, $401 \mathrm{pp}$.

Hussain, S.M. 1998. Recent benthic Ostracoda from the Gulf of Mannar, off Tuticorin, southeast coast of India. Journal of the Palaeontological Society of India, 43: 1-22.

Hussain, S.M. \& Mohan, S.P. 2001. Distribution of Recent benthic Ostracoda in Adyar river estuary, east coast of India. Indian Journal of Marine Sciences, 30: 53-56.

Ishizaki, K. 1968. Ostracodes from Ouranouchi Bay, Kochi Prefecture, Japan. Science Reports of the Tohoku University, Series 2 (Geology), 40 (1): 1-45.

Jain, S.P. 1978. Recent Ostracoda from Mandvi Beach, West Coast of India. Bulletin, Indian Geologists Association, 11 (2): 89-139.

Jellinek, T. 1993. Zur Ökologie und Systematik rezenter Ostracoden aus dem Bereich des kenianischen Barriere-Riffs. Senckenbergiana lethaea, 73 (1): 83-225.

Jones, T.R. 1849. A Monograph of the Entomocostraca of the Cretaceous Formation of England. Monograph. Palaeontographical Society, London, 40pp.

Keij, A.J. 1953. Preliminary note on the Recent Ostracoda of the Snellius Expedition. Proceedings Koninklijke Nederlandse Akademie van Wetenschappen, Series B, 56 (2): 155-168.

Keij, A.J. 1954. Some Recent Ostracoda of Manila (Philippines). Proceedings Koninklijke Nederlandse Akademie van Wetenschappen, Series B, 57 (3): 351-363.

Khosla, S.C. \& Nagori, M.L. 1989. Ostracoda from the Quilon Beds (Lower Miocene) of Kerala. Geological Society of India, Memoir, 14: $57 \mathrm{pp}$.

Kingma, J. Th. 1948. Contributions to the knowledge of the Young Caenozoic Ostracoda from the Malayan Region. PhD dissertation. University of Utrecht, Utrecht, 119pp.

Liebau, A. 1975. Comment of suprageneric taxa of the Trachyleberididae S. N. (Ostracoda, Cytheracea). Neues Jahrbuch für Geologie und Paläontologie, Abhandlungen, 148 (3): 353-379.

Maddocks, R.F. 1966. Distribution patterns of living and subfossil podocopid ostracods in the Nosy Bé area, northern Madagascar. University of Kansas Palaeontological Contributions, 12: 1-72.

McKenzie, K.G. 1974. Cenozoic Ostracoda of southeastern Australia with the description of Hanaiceratina new genus. Geoscience and Man, 6: $153-182$

McKenzie, K.G. 1986. A comparative study of collections from the S.W. Pacific (Saipan to Tonga), with the description of Gambiella caudata (Brady, 1890) and a new species of Pterobairdia (Ostracoda). Journal of Micropalaeontology, 5 (1): 91-108.

McKenzie, K.G. \& Swain, F.M. 1967. Recent Ostracoda from Scammon lagoon, Baja California. Journal of Paleontology, 41: 281-305.

McKenzie, K.G., Reyment, R.A. \& Reyment, E.R. 1990. Pleistocene and recent Ostracoda from Goose Lagoon Drain, Victoria and Kingston, South Australia. Bulletin of the Geological Institutions of the University of Uppsala, N.S., 16: 1-46.

Mohan, S.P., Ravi, G., Hussain, S.M. \& Rajeshwara, R. 2001. Recent Ostracoda from the Bay of Bengal, off the Karikkattukuppam (near Chennai), South East Coast of India. Journal of the Palaeontological Society of India, 46: 1-14. 
Morkhoven, F.P.C.M. van 1963. Post Paleozoic Ostracoda, vol. 2. Their morphology, taxonomy and economic use. Elsevier, Amsterdam, 478pp.

Müller, G.W. 1894. Die Ostracoden des Golfes von Neapel und der angrenzenden Meeres-abschnitte. Fauna und Flora des Golfes von Neapel und der angrenzenden Meeresabschnitte, 21: 1-404.

Münster, G.G. von 1830. Über einige fossile Arten Cypris (Müller, Lamk.) und Cythere (Müller, Latreille, Desmarest). Jahrbuch für Minerologie, Geognoisie, Geologie und Petrefaktenkunde, 1: 60-67.

Neviani, A. 1928. Ostracodi fossili d'Italia - 1: Vallebiaja (Calabriano). Memorie della Pontifici Academie della Science-Nuovo Lincei, 81: $123-132$.

Oertli, H.J. 1956. Ostrakoden aus der oligozanen und miozanen molasse der Schewiz. Schweizerische Paläontologische Abhandlungen, Basel, 74 (1): $1-119$.

Pokorny, V. 1955. Contribution to the morphology and taxonomy of the subfamily Hemicytherinae Puri, 1953 (Crustacea, Ostracoda). Acta Universitatis Carolinae, Geologica, 1955 (3): 1-35.

Pokorny, V. 1970. The genus Radimella Pokorny, 1969 (Ostracoda, Crustacea) in the Galapagos Islands. Acta Universitatis Carolinae, Geologica, 1969 (4): 293-334.

Puri, H.S. 1953. The ostracode genus Hemicythere and its allies. Journal of the Washington Academy of Sciences, 43 (6): 169-179.

Puri, H.S. 1954. Contributions to the study of the Miocene of the Florida Panhandle. Part 3, Ostracoda. Geological Bulletin, State of Florida, State Board of Conservation, Florida Geological Survey, 36 (1953): 2125-2345.

Puri, H.S. 1957a. Henryhowella, a new name for Howella Puri, 1956. Journal of Palaeontology, 31 (5): 982.

Puri, H.S. 1957b. Stratigraphy and zonation of the Ocala Group, part 3. Florida Geological Survey, Geological Bulletin, 38: 187-248.

Puri, H.S. \& Hulings, N.C. 1976. Designation of lectotypes of some ostracods from the "Challenger" Expedition. Bulletin of the British Museum (Natural History). (Zoology), 29 (5): 249-315.

Reuss, A.E. 1850. Die fossilien Entomostraceen des Osterreichen Tertiarbeckens. Naturwissenschaftliche Abhandlungen. 1 Abteilung, 3 (1): 41-92.

Ruggieri, G. 1956. La suddivisione degli Ostracodi gia compresi nel genere Cythereis proposta da Neviani nel 1928. Società Italiana di Scienze Naturali Atti, 95 (2): 161-175.

Sars, G.O. 1866. Oversigt af Norges marine Ostracoder. Forhandlinger $i$ Videnskabsselskabet i Kristiania(for 1865): 1-130.

Sissingh, W. 1972. Late Cenozoic Ostracoda of the South Aegean Island Arc. Utrecht Micropalaeontological Bulletin, 6: 1-187.

Tabuki, R. \& Nohara, T. 1995. Seasonal distribution of intertidal ostracodes on gravels from the moat behind a coral reef off Sesoko Island, Ryukyu Island, Japan. In: Riha, J. (Ed.), Ostracoda and Biostratigraphy. Balkema, Rotterdam, 343-349.

Teeter, J.W. 1975. Distribution of Holocene marine Ostracoda from Belize. In: Wantland, K.T. \& Puseu, W.C. (Eds), Belize shelf carbonate sediments and ecology. American Association of Petroleum Geologists Studies in Geology, 2: 400-499.

Titterton, R. \& Whatley, R.C. 1988. Recent Bairdiinae (Crustacea, Ostracoda) from the Solomon Islands. Journal of Micropalaeontology, 7 (2): 111-142.

Titterton, R. \& Whatley, R.C. 2005. Recent marine Ostracoda from the Solomon Islands. Part 2: Cytheracea, Xestoleberidae. Revista Española de Micropaleontología, 37 (2): 291-313.

Titterton, R. \& Whatley, R.C. 2006a. Recent marine Ostracoda from the Solomon Islands. Part 1: Cypridoidea, Platycopina and Cladocopina. Journal of Micropaleontology, 25 (1): 73-94.
Titterton, R. \& Whatley, R.C. 2006b. Recent marine Ostracoda from the Solomon Islands. Part 3. Cytheroidea, Bythocytheridae, Cytherideidae, Krithidae, Neocytherideidae, Cytheruridae. Revista Española de Micropaleontología, 38 (1): 169-189.

Valicenti, V.H. 1977. Some Hemicytherinae from the Tertiary of Patagonia (Argentina), their morphological relationship and stratigraphical distribution. Sixth international ostracod symposium Saalfelden (Austria). W. Junk, The Hague, 93-106.

Warne, M., Whatley, R.C. \& Blagden, B. 2006. Ostracoda from Lee Point on Shoal Bay, northern Australia: Part 3. Podocopina, (Cytheracea). Revista Española de Micropaleontología, 38 (1): 103-167.

Whatley, R.C. 2000. The zoogeographical significance of the Easter Island fauna. Revista Española de Micropaleontología., 32 (2): $147-156$.

Whatley, R.C. \& Jones, R.L. 1999. The marine podocopid Ostracoda of Easter Island; a paradox in zoogeography and evolution. Marine Micropalaeontology, 37: 327-343.

Whatley, R.C. \& Keeler, N.P. 1989. Ostracodes actuels de l'île de la Réunion (Sud-Oeste de l'Océan Indien). Revue de Micropaléontologie, 32: $63-84$

Whatley, R.C. \& Roberts, R. 1995. Marine Ostracoda from Pitcairn, Oeno and Henderson Islands. In: Benton, T.G. \& Spencer, T. (Eds), The Pitcairn Islands: biogeography, ecology and prehistory. Biological Journal of the Linnean Society, 56: 359-364.

Whatley, R.C. \& Titterton, R. 1981. Some new Recent podocopid Ostracoda from the Solomon Island, South-West Pacific. Revista Española de Micropaleontología, 13 (2): 157-170.

Whatley, R.C., Jones, R.L. \& Wouters, K. 2000. The Ostracoda of Easter Island. Revista Española de Micropaleontología, 32 (1): 79-106. Whatley, R.C., Jones, R.L. \& Roberts, R. in press a. The marine Ostracoda of Pitcairn, Oeno and Henderson Islands, southern Pacific. Revista Española de Micropaleontología.

Whatley, R.C., Williams, U., Pyne, R. \& Titterton, R. in press b. Quaternary marine and brackish water Ostracoda from the Solomon Islands. Revista Española de Micropaleontología.

Williams, E.U. 1980. MS. Some Quaternary Ostracoda from the Solomon Islands. Unpublished MSc dissertation. University of Wales, Aberystwyth, 183pp.

Yassini, I. \& Jones, B.G. 1987. Ostracoda from Lake Illawara: environmental factors, assemblages and systematics. Australian Journal of Marine and Freshwater Research, 38: 793-843.

Yassini, I. \& Jones, B.G. 1995. Foraminifera and Ostracoda from Estuarine and Shelf Environments on the Southern Coast of Australia. The University of Woolagong Press, Woolagong, 484pp.

Yassini, I. \& Wright, A.J. 1988. Distribution and ecology of Recent ostracodes (Crustacea) from Port Hacking, New South Wales. Proceedings of the Linnean Society of New South Wales, 110 (2): 159-174.

Zhao, Q. \& Wang, P. 1988. Distribution of Modern Ostracoda in the Shelf Seas off China. In: Hanai, T., Ikeya, N. \& Ishizaki, K. (Eds), Evolutionary biology of Ostracoda, its fundamentals and applications. Proceedings of the 9th International Symposium on Ostracoda. Shizuoka, Japan, 1985. Developments in Palaeontology and Stratigraphy, 11. Kodansha/Elsevier, Oxford, 805-821.

Zhao, Q. \& Whatley, R.C. 1989a. Recent podocopid Ostracoda of the Sedili River and Jason Bay, Southeastern Malay Peninsula. Micropaleontology, 35: 168-187.

Zhao, Q. \& Whatley, R.C. 1989b. A taxonomic revision of the new species of Ostracoda described by J. T. Kingma (1948) from the late Cainozoic of Indonesia. Acta Micropalaeontologica Sinica, 6(3): 229-246. [In English with Chinese abstract.]. 